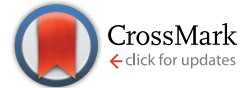

Cite this: Chem. Sci., 2017, 8, 348

Received 27th June 2016

Accepted 13th August 2016

DOI: $10.1039 / c 6 s c 02837 c$

www.rsc.org/chemicalscience

\section{Luminescent ion pairs with tunable emission colors for light-emitting devices and electrochromic switches $\dagger$}

\author{
Song Guo, $\neq^{a}$ Tianci Huang, $\neq^{a}$ Shujuan Liu, ${ }^{a}$ Kenneth Yin Zhang, ${ }^{a}$ Huiran Yang, ${ }^{a}$ \\ Jianmei Han, ${ }^{a}$ Qiang Zhao*a and Wei Huang*ab
}

\begin{abstract}
Most recently, stimuli-responsive luminescent materials have attracted increasing interest because they can exhibit tunable emissive properties which are sensitive to external physical stimuli, such as light, temperature, force, and electric field. Among these stimuli, electric field is an important external stimulus. However, examples of electrochromic luminescent materials that exhibit emission color change induced by an electric field are limited. Herein, we have proposed a new strategy to develop electrochromic luminescent materials based on luminescent ion pairs. Six tunable emissive ion pairs (IP1-IP6) based on iridium(III) complexes have been designed and synthesized. The emission spectra of ion pairs (IPs) show concentration dependence and the energy transfer process is very efficient between positive and negative ions. Interestingly, IP6 displayed white emission at a certain concentration in solution or solid state. Thus, in this contribution, UV-chip (365 nm) excited light-emitting diodes showing orange, light yellow and white emission colors were successfully fabricated. Furthermore, IPs displayed tunable and reversible electrochromic luminescence. For example, upon applying a voltage of $3 \mathrm{~V}$ onto the electrodes, the emission color of the solution of IP1 near the anode or cathode changed from yellow to red or green, respectively. Color tunable electrochromic luminescence has also been realized by using other IPs. Finally, a solid-film electrochromic switch device with a sandwiched structure using IP1 has been fabricated successfully, which exhibited fast and reversible emission color change.
\end{abstract}

\section{Introduction}

Luminescent materials have attracted considerable attention because of their wide applications in displays, data recording and storage, chemical sensing, bioimaging, etc. ${ }^{\mathbf{1 - 9}}$ Emissive materials with tunable luminescence colors are of great significance for their optical applications. Up to now, conventional methods for tuning the photophysical properties of luminescent materials are mainly limited to the modification of the chemical structures, such as the change of $\pi$-conjugation skeletons or the introduction of functional groups. ${ }^{10-21}$ However, this method often requires complicated synthetic processes and tedious purification procedures. Stimuli-responsive

${ }^{a}$ Key Laboratory for Organic Electronics and Information Displays and Institute of Advanced Materials (IAM), Jiangsu National Synergetic Innovation Center for Advanced Materials (SICAM), Nanjing University of Posts and Telecommunications (NUPT), Nanjing 210023, P. R. China.E-mail: iamqzhao@njupt.edu.cn

${ }^{b}$ Key Laboratory of Flexible Electronics (KLOFE) and Institute of Advanced Materials (IAM), Jiangsu National Synergetic Innovation Center for Advanced Materials (SICAM), Nanjing Tech University (NanjingTech), Nanjing 211816, P. R. China. E-mail:wei-huang@njtech.edu.cn

$\dagger$ Electronic supplementary information (ESI) available: Details of NMR and MS spectra. See DOI: 10.1039/c6sc02837c

\$ S. Guo and T. Huang contributed equally to this work. luminescent materials have attracted increasing interest, because they can exhibit tunable emissive properties which are sensitive to external physical stimuli, such as light, temperature, force, electric field, etc. ${ }^{22-28}$ Among these stimuli, electric field is an important external stimulus, which can be conveniently combined with the current semiconductor technology in electronic devices. ${ }^{29-33}$ Recently, electrochromic luminescent materials that exhibited emission color changing induced by an electric field have been reported (Fig. 1a). For example, Chidichimo and co-workers have presented $\pi$-conjugated ionic liquid crystals in which the direct electrochemical reduction leads to a reversible electrochromic luminescence (ECL) response. ${ }^{34}$ Beneduci and co-workers have shown an ECL-active polymer gel based on the conversion of the redox states, in which the emission properties of the polymer depend on the fluorophore contents and the voltages applied..$^{35}$ We have also reported a series of phosphorescent iridium(III) complexes containing a protonating functional group, which exhibited evident emission color change induced by an electric field. ${ }^{36-38}$ However, special functional groups, such as redox active or protonating groups, in these electrochromic luminescent materials may reduce their stability, especially toward redox reagents and $\mathrm{pH}$ values. Therefore, it is urgent to explore a new 
a

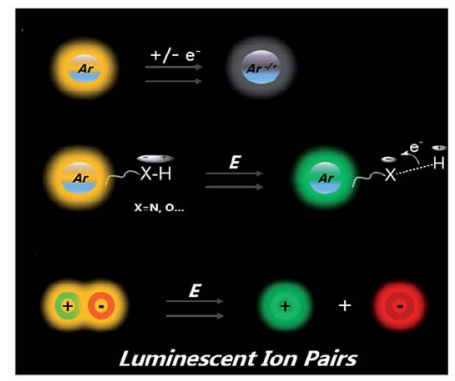

c
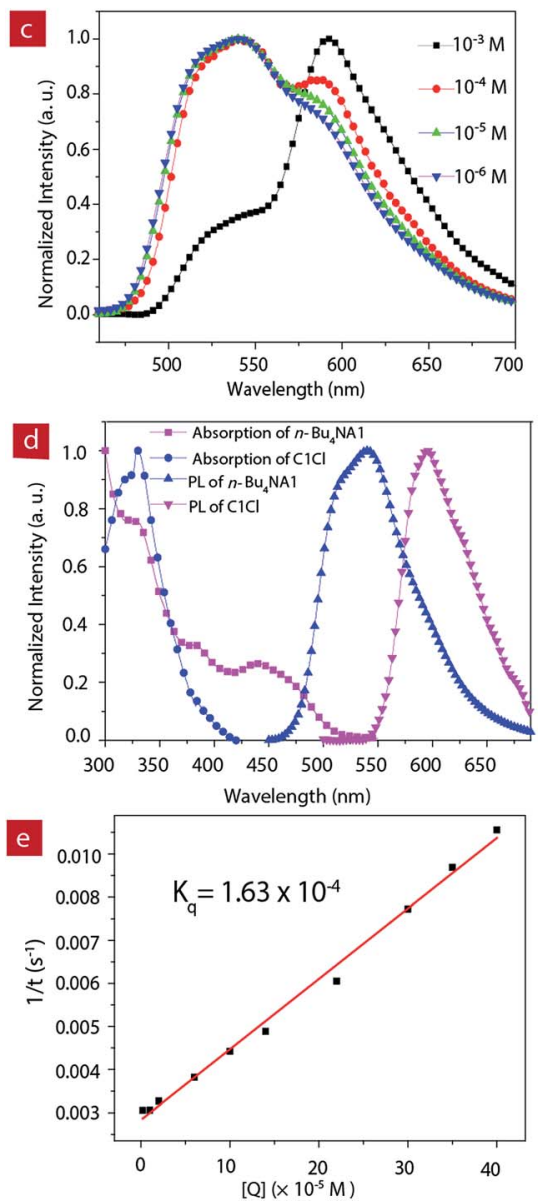

b
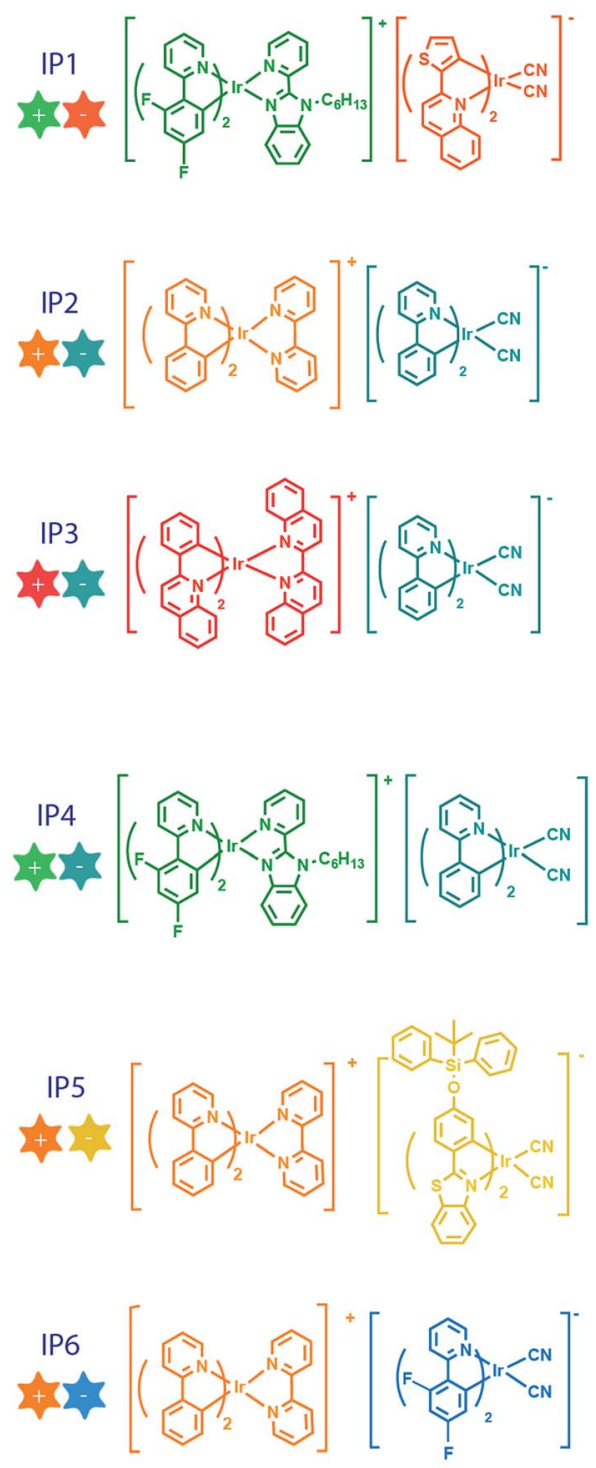

Fig. 1 (a) The design principles of electrochromic luminescent materials. (b) The structures of six ion pairs. (c) Luminescence spectra of IP1 at different concentrations in acetonitrile. (d) Absorption and luminescence spectra of $\mathrm{C} 1 \mathrm{Cl}$ and $n-\mathrm{Bu}_{4} \mathrm{NA1}\left(10^{-5} \mathrm{M}\right)$. (e) Stern-Volmer plot of the quenching study between $\mathrm{C} 1 \mathrm{Cl}$ and $n-\mathrm{Bu}_{4} \mathrm{NA} 1$ and the numerical fitting of $K_{\mathrm{q}}$.

generation of electrochromic luminescent materials with controllable emission colour change.

Ion pairs (IPs) consist of an anionic and a cationic component which are bonded together with electrostatic and van der Waals interactions. Employment of emissive anionic and cationic components yields luminescent IPs showing a mixed luminescence color. ${ }^{39-43}$ Compared to single luminophores, IPs containing two luminescent chromophores exhibit richer excited states, which results from potential energy transfer between the two luminophores. In addition, IPs exhibit a "single-component" characteristic and can avoid phase separation in the solid state, which usually occurs in a physical mixture of two luminophores.
In this work, we aim to develop luminescent IPs with tunable emissive colors. Owing to the advantageous photophysical properties of phosphorescent iridium(III) complexes, such as high luminescence quantum yields, long emission lifetimes, large Stokes shifts, high photostability, and photophysical properties sensitive to the microenvironment, a series of positively- and negatively-charged iridium(III) complexes have been chosen as the cationic and anionic components of luminescent IPs (IP1-IP6, Fig. 1b), respectively. ${ }^{44-53}$ Upon photoexcitation, these IPs exhibited a mixed luminescence from both the cation and the anion. The emission spectra of IP1-IP6 show concentration dependence. In particular, IP6 displayed white emission at a suitable concentration in solution or solid state. Thus, in 
this contribution, UV-chip (365 nm) excited light-emitting diodes (LEDs) showing orange, light yellow and white emission colors were successfully fabricated using IP6 as the emitter. In addition, interesting and tunable electrochromic luminescence has been observed in solution and quasi-solid devices, and the electrochromic mechanism of these IPs has been investigated.

\section{Results and discussion}

\section{Synthesis and characterizations}

The photophysical properties of iridium(III) complexes are closely related to their ligands. Hence, to obtain IPs showing different luminescent colors, various cationic and anionic complexes $\left(\left(\mathrm{C}^{\wedge} \mathrm{N}\right)_{2} \operatorname{Ir}\left(\mathrm{N}^{\wedge} \mathrm{N}\right)^{+} \mathrm{Cl}^{-}\right.$and $\left.\left(\mathrm{C}^{\wedge} \mathrm{N}\right)_{2} \operatorname{Ir}(\mathrm{CN})_{2}-n-\mathrm{Bu}_{4} \mathrm{~N}^{+}\right)$with different $\mathrm{HC}^{\wedge} \mathrm{N}$ ligands $\left(\mathrm{HC}^{\wedge} \mathrm{N}=2\right.$-phenylpyridine, 2-phenylquinoline, 2-(2,4-disfluorophenyl)pyridine, 2-thiophenylquinoline, $N$-hexyl-2-(2-pyridyl)benzimidazole, 2-(4-((tert-butyldiphenylsilyl)oxy)phenyl)-phenylbenzothiazole; $\mathrm{N}^{\wedge} \mathrm{N}=2,2^{\prime}$-biquinoline, 2,2'-dipyridine, cyanide) were selected to prepare the luminescent IPs and the emission colors of these complexes cover the entire visible region. The luminescent IPs were synthesized in two steps. Firstly, three cationic (C1Cl-C3Cl) and four anionic complexes $\left(\boldsymbol{n}\right.$-Bu $\mathbf{B u}_{\mathbf{4}} \mathbf{N A 1}-\boldsymbol{n}$-Bu $\left.\mathbf{H}_{4} \mathbf{N A 4}\right)$ were synthesized by refluxing biscyclometalated iridium(III) dichloro-bridged dimers in the presence of an excess of auxiliary $\mathrm{N}^{\wedge} \mathrm{N}$ or $\mathrm{CN}^{-}$ ligands. In the second step, six IPs without small counterions, IP1-IP6 (C1A1, C2A2, C3A2, C1A2, C2A3 and C2A4), were obtained by the metathesis reactions (Schemes 1 and S1†). ${ }^{43,54-58}$

All the complexes and IPs have been fully characterized by ${ }^{1} \mathrm{H}$ nuclear magnetic resonance (NMR), ${ }^{13} \mathrm{C}\left\{{ }^{1} \mathrm{H}\right\} \mathrm{NMR},{ }^{19} \mathrm{~F}$ $\left\{{ }^{1} \mathrm{H}\right\}$ NMR, matrix-assisted laser desorption ionization timeof-flight mass spectrometry (MALDI-TOF MS), electrospray ionization mass spectrometry (ESI-MS) (see ESI $\dagger$ ), UV-Vis absorption spectrometry and steady-state photoluminescence (PL) spectrometry. In ${ }^{1} \mathrm{H}$ NMR spectra, the anionic complexes exhibited four peaks at 3.06, 1.58, 1.34 and $0.96 \mathrm{ppm}$ in $\mathrm{CD}_{3} \mathrm{CN}$, which can be assigned to the tetrabutylammonium cation. These signals were absent in the ${ }^{1} \mathrm{H}$ NMR spectra of IPs, indicating the successful metathesis reaction and the quantitative synthesis of the IPs starting from equal molar quantity of the two luminescent components in dichloromethane.

\section{Photophysical properties}

The photoluminescence properties of the complexes were investigated. The PL spectra of the cationic (C1Cl-C3Cl) and anionic $\left(\boldsymbol{n}-\mathbf{B u}_{4} \mathbf{N A 1}-\boldsymbol{n}-\mathbf{B u} \mathbf{u}_{4} \mathbf{N A 4}\right)$ complexes in acetonitrile solution are presented in Fig. 1d and Fig. S3, $\dagger$ peaking at 524, 591, 638, 550, 595, 475 and $523 \mathrm{~nm}$, respectively. For the IPs, their emissions are contributed to by both cations and anions. Interestingly, the PL spectra of the IPs exhibit concentration dependence (Fig. S1†). Taking IP1 as an example (Fig. 1c), at a relatively low concentration of $10^{-6} \mathrm{M}$, the emission peak of IP1 is around $524 \mathrm{~nm}$, which originated from C1, because the quantum yield of $\mathbf{C 1}(21 \%)$ is much higher than that of $\mathbf{A 1}$ $(17 \%)$. As the concentration of solution increases, the green

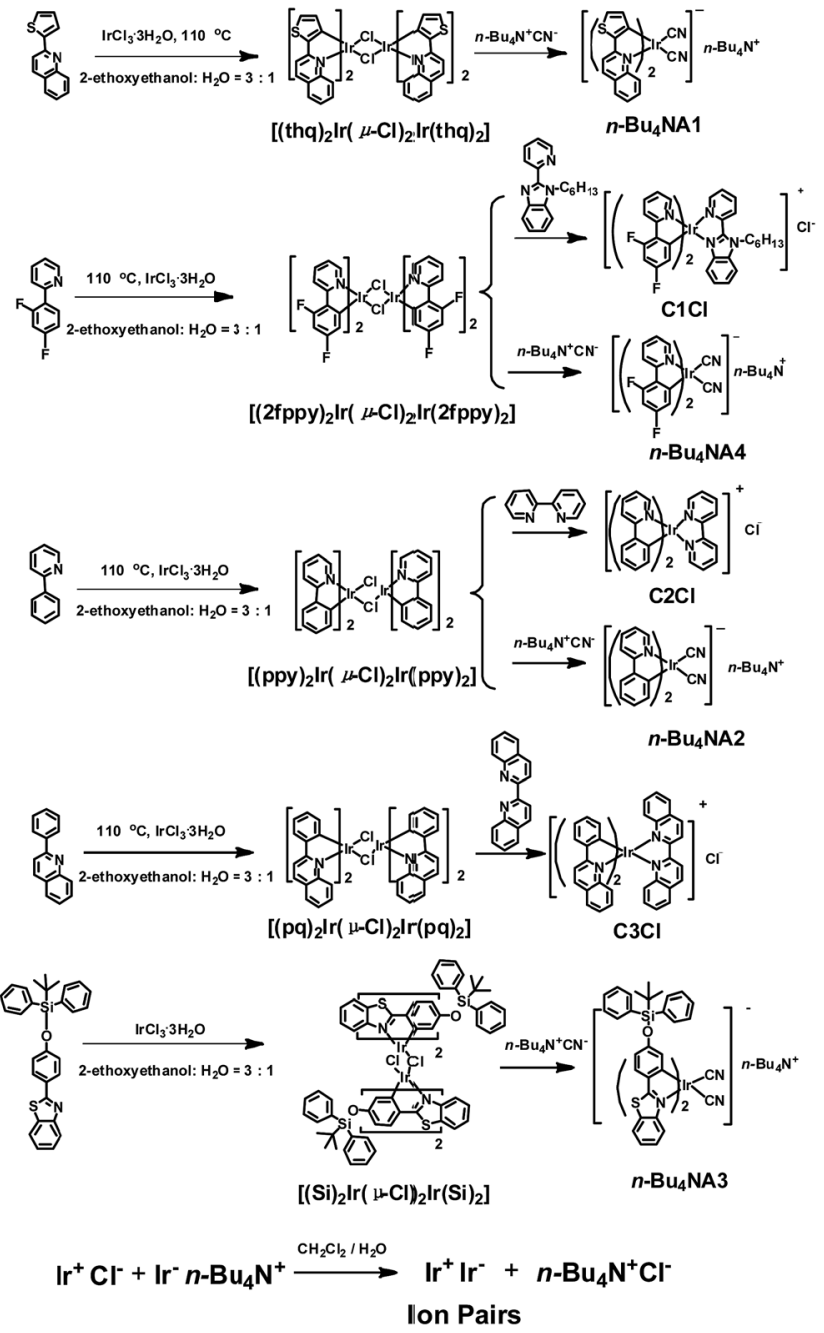

Scheme 1 The synthetic routes of positive and negative Ir(III) complexes and ion pairs.

emission from $\mathbf{C} 1$ was quenched by the anionic complex A1, due to energy transfer from $\mathbf{C 1}$ to A1. When the concentration of IP1 was increased to $10^{-3} \mathrm{M}$, the PL spectrum is dominated by the emission from the anionic component. The emission spectra of IP1-IP6 were also measured in various solvents (THF, ethyl acetate, $\mathrm{CHCl}_{3}, \mathrm{CH}_{2} \mathrm{Cl}_{2}, \mathrm{CH}_{3} \mathrm{OH}$ ), and there was no evident change in different solvents at the same concentration of IPs as shown in Fig. S2. $\dagger$

The energy transfer process between the two components of IP1 was investigated by Stern-Volmer quenching analysis (Fig. 1d and e). The quenching study was based on a bimolecular quenching model, $\tau_{0} / \tau=1+K_{\mathrm{q}} \tau_{0}[\mathrm{Q}]$, where $\tau$ and $\tau_{0}$ are the emission lifetimes of $\boldsymbol{n}$ - $\mathbf{B u}_{\mathbf{4}} \mathbf{N A 1}$ with and without the quencher $\mathbf{C 1 C l}, K_{\mathrm{q}}$ is the experimental quenching rate constant and $[\mathrm{Q}]$ is the molar concentration of the quencher. The lifetimes of $\boldsymbol{n}-\mathbf{B u}_{\mathbf{4}} \mathbf{N A 1}$ in acetonitrile solution with various amounts of the quencher, $\mathbf{C 1 C l}$, were measured. The concentration of $\boldsymbol{n}-\mathrm{Bu}_{4} \mathrm{NA1}$ was kept at $1.0 \times 10^{-5} \mathrm{M}$, while that of $\mathbf{C 1 C l}$ varied from 0 to $4.0 \times 10^{-4} \mathrm{M}$. The Stern-Volmer plot of the mixture of the two complexes in solution revealed 
a good linear relationship between $\tau_{0} / \tau$ and [Q]. The calculation yields a $K_{\mathrm{q}}$ value of $1.63 \times 10^{-4} \mathrm{M}^{-1} \mathrm{~s}^{-1}$. This quenching effect can be attributed to the intermolecular triplet-triplet energy transfer. ${ }^{\mathbf{4 3} 46}$ The results indicate that the energy transfer quenching process is very efficient between the two ionic complexes.

\section{White LED devices}

For IP6, the two luminescent components peak at $475 \mathrm{~nm}$ and $580 \mathrm{~nm}$. At a concentration of $1.0 \times 10^{-3} \mathrm{M}$, the ion pair shows orange emission. With the decrease of concentration in $\mathrm{CH}_{3} \mathrm{CN}$, the greenish-blue emission increases gradually (Fig. 2a and c). When the concentration decreases to $6.5 \times 10^{-6} \mathrm{M}$, the solution exhibits white emission with the Commission Internationale de L'Eclairage (CIE) of $(0.28,0.30)$ and a quantum efficiency of 0.22 . As the concentration continues to decrease, the solution shows weak blue emission.

IP6 was doped into a polyethylene-polypropylene glycol polymer to investigate the photophysical properties of the solid film. At different doping concentrations, the film showed different emission colors (Fig. $2 \mathrm{~b}$, and $\mathrm{S} 4 \dagger$ ). At a concentration of about $1.9 \mathrm{mg}$ IP6 in $800 \mathrm{mg}$ polymer, the solid film exhibited orange emission. With the decrease of the doping concentration, the solid film showed light yellow emission gradually. Finally, when the concentration decreased to about $0.7 \mathrm{mg}$ IP6 in $800 \mathrm{mg}$ polymer, the solid film showed white emission with a quantum efficiency of 0.16. IP6, therefore, is a potential candidate material for white LED (WLED).

Compared to the widely used inorganic phosphors, organic emitters have a greater advantage due to their large absorption cross section, which can reduce the phosphor consumption and cut down the costs..$^{59}$ Here, to fabricate the near-UV excited LED, powdered organic emitter IP6 was dispersed in a polyethylenepolypropylene glycol polymer and then coated onto the surface of commercially available $365 \mathrm{~nm}$ UV LED chips. Bright orange, light yellow and white emission were obtained when polyethylene-polypropylene glycol polymers doped with different concentrations $(1.9 \mathrm{mg} / 800 \mathrm{mg}, 0.9 \mathrm{mg} / 800 \mathrm{mg}$ and $0.7 \mathrm{mg} / 800 \mathrm{mg}$ ) of IP6 were coated onto the UV chip as emitters. We can clearly see the bright orange, light yellow and white emissions from the prepared devices with CIE coordinate values of $(0.51,0.47),(0.40,0.41)$ and $(0.31,0.36)$, respectively (Fig. 2d).

\section{Electrochromic switches}

Considering that IPs consist of luminescent ions with opposite charges, the electric field is anticipated to regulate the luminescent behavior. In order to demonstrate this behavior, IP1 was used to perform the electrochromic luminescence experiment as illustrated in Fig. 3a. A concentration of $10^{-5} \mathrm{M}$ of the ion pair was chosen, because the emission intensity of the two peaks of IP1 was almost equal at this concentration. Two plat-

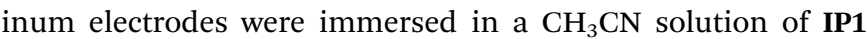
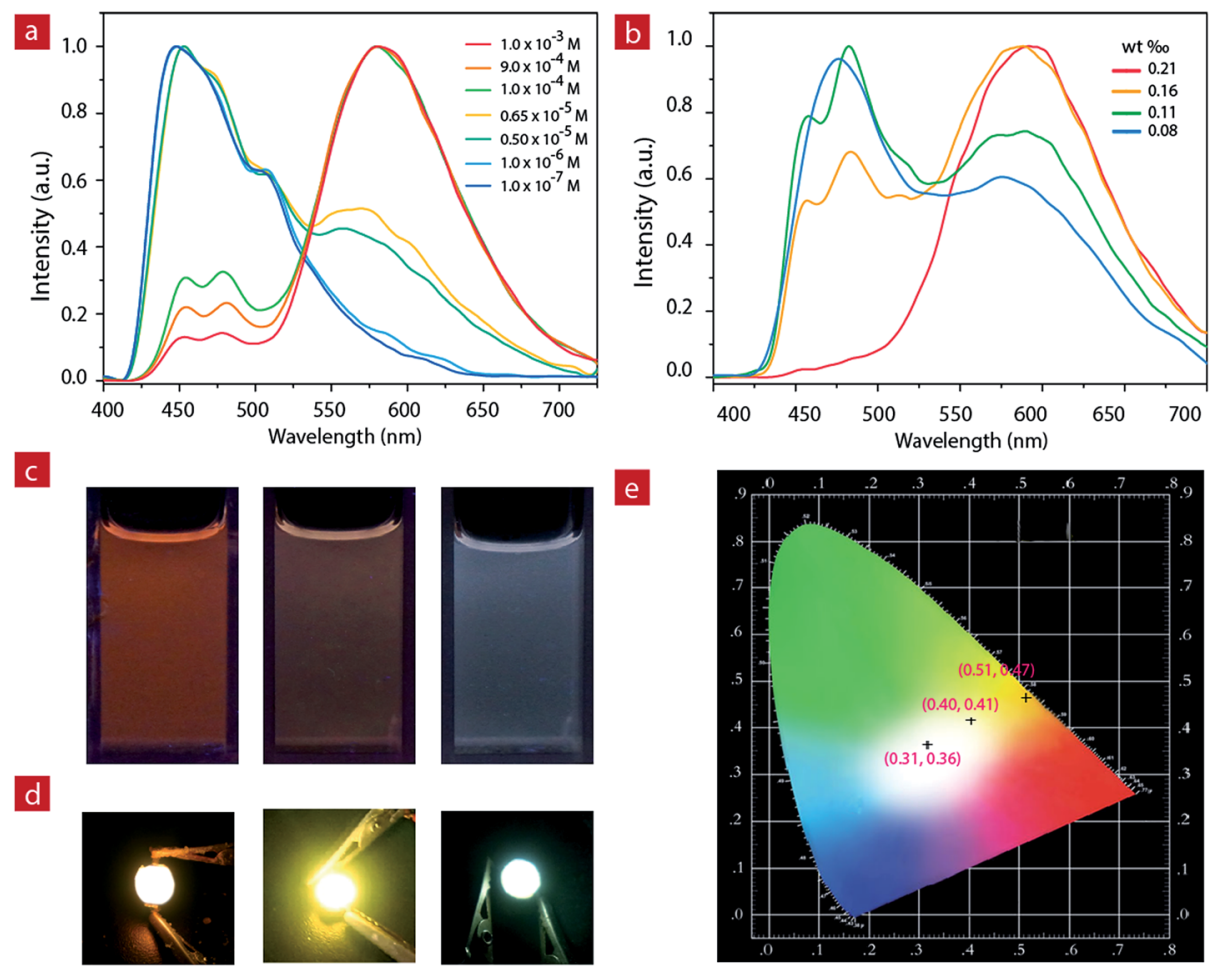

Fig. 2 (a) The luminescence spectra of IP6 at different concentrations in acetonitrile. (b) The solid state luminescence spectra of IP6 doped into a polyethylene-polypropylene glycol polymer with different weight ratios. (c) Photographs of IP6 at different concentrations (left, $1.0 \times 10^{-3} \mathrm{M}$; middle, $1.0 \times 10^{-4} \mathrm{M}$; right, $6.5 \times 10^{-6} \mathrm{M}$ ) in acetonitrile under excitation at $365 \mathrm{~nm}$. (d) The pictures of the orange (left, $1.7 \mathrm{mg}$ in $800 \mathrm{mg}$ ), lightyellow (middle, $0.9 \mathrm{mg}$ in $800 \mathrm{mg}$ ) and white (right, $0.7 \mathrm{mg}$ in $800 \mathrm{mg}$ ) LEDs operated at $3.5 \mathrm{~V}$. (e) CIE 1931 chromaticity diagram of the obtained orange, light-yellow and white light from the fabricated LED devices. 

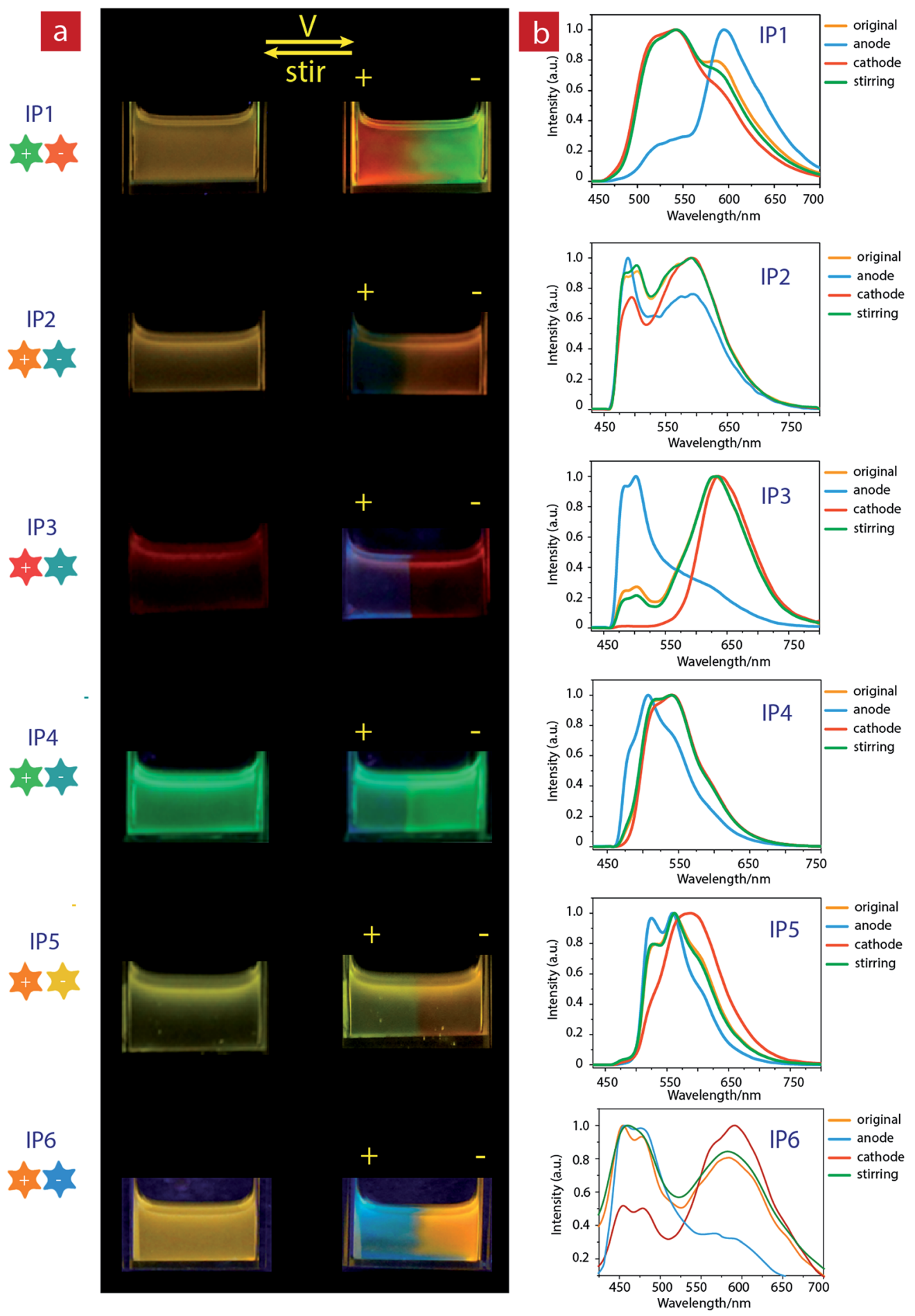

Fig. 3 (a) Photographs of ion pairs $\left(10^{-5} \mathrm{M}\right)$ in acetonitrile before (left) and after (right) applying a voltage of $3 \mathrm{~V}$, followed by stirring and reversing the voltage under excitation at $365 \mathrm{~nm}$. (b) Luminescence spectra of ion pairs $\left(10^{-5} \mathrm{M}\right)$ in acetonitrile before and after applying a voltage at the cathode and anode, respectively.

with a distance of $20 \mathrm{~mm}$ between each other. Before applying a voltage, the solution of IP1 exhibited yellow emission. Subsequently, upon applying a voltage of $3 \mathrm{~V}$ onto the electrodes, the emission color of the solution near the anode changed from yellow to red within $30 \mathrm{~s}$, which is in accordance with its cationic component (C1). Meanwhile, the yellow emission near the cathode changed to green, which is same as that of the anionic component (A1). Such a change of emission color gradually extends to the middle of the two electrodes, appearing as a clear boundary.

Then once the voltage was removed, the original yellow emission was recovered after stirring the solution and the 
electrochromic luminescence reappeared when the stirring was stopped. This observation indicates that IP1 shows an excellent reversibility for electrochromic luminescence. To explore the mechanism of this phenomenon, the emission spectra of IP1 near the anode and cathode after electrical stimuli are measured and shown in Fig. 3b. It was found that the emission spectra of the solution near the anode and cathode are almost the same as those of the anionic $\left(\boldsymbol{n}\right.$-Bu $\left.\mathbf{B u}_{\mathbf{4}} \mathbf{N A 1}\right)$ and cationic iridium(III) complex (C1Cl), respectively. Therefore, we believe that the anionic component directionally moves to the anode and the cationic one shifts to the cathode because the electrostatic interaction was broken under an electric field, resulting in the emission color changes near the two electrodes.

To have a better understanding of these observations, a schematic model was proposed in Fig. 4e. Before applying a voltage, the IPs were disordered and uniformly distributed in the solution, and the interaction between cationic and anionic components is mainly through electrostatic force, which can be broken upon applying a voltage, leading to migration of cationic and anionic components to the cathode and anode, respectively. After removing the voltage and stirring the solution, the two components held together again. This mechanism was confirmed by the NMR experiments. Because of the asymmetry of the ancillary ligand in $\mathbf{C 1 C l}$, the two $\mathrm{C}^{\wedge} \mathrm{N}$ ligands are non-chemically equivalent. There are two peaks attributed to the proton in the b-position with each integral of 1 (Fig. $\mathrm{S} 5 \dagger$ ). For $\boldsymbol{n}$-Bu $\mathbf{B u}_{\mathbf{4}} \mathbf{N A 1}$, the two $\mathrm{C}^{\wedge} \mathrm{N}$ ligands are chemically equivalent owing to the symmetry of the ancillary ligands $\mathrm{CN}^{-}$ in the structure. Eight peaks from the $\mathrm{C}^{\wedge} \mathrm{N}$ ligand could be observed in the NMR spectrum. The integral of the proton in the a-position is 2. In the original NMR spectrum of IP1, the integral ratio of protons at the a-position to the b-position is $2: 1$, indicating that the anion and cation are equal. After applying a voltage, the integral ratio in the NMR spectrum of the solution near the cathode changed to $0.56: 1.00$, while that near the anode changed to $2.00: 0.82$. These results demonstrated the migration of anions and cations to anode and cathode, respectively, under the electric field.

To prove that the formation of IPs is necessary for realizing this electrochromism phenomenon, a control experiment using a mixed solution of $\boldsymbol{n}$-Bu $\mathbf{H}_{\mathbf{4}} \mathbf{N A 1}$ and $\mathbf{C 1 C l}$ (molar ratio $1: 1$ ) was carried out. Upon applying a voltage of $3 \mathrm{~V}$ to the electrodes for about 2 minutes, no emission color change was observed (Fig. S6†), which may be because the small counterions $\mathbf{C l}^{-}$and $\boldsymbol{n}$ - $\mathbf{B u _ { 4 }} \mathbf{N}^{+}$moved to the anode and cathode preferentially compared to the bulky ionic iridium(III) complexes. Hence, our design strategy based on luminescent IPs is effective to realize the electrochromic luminescence.

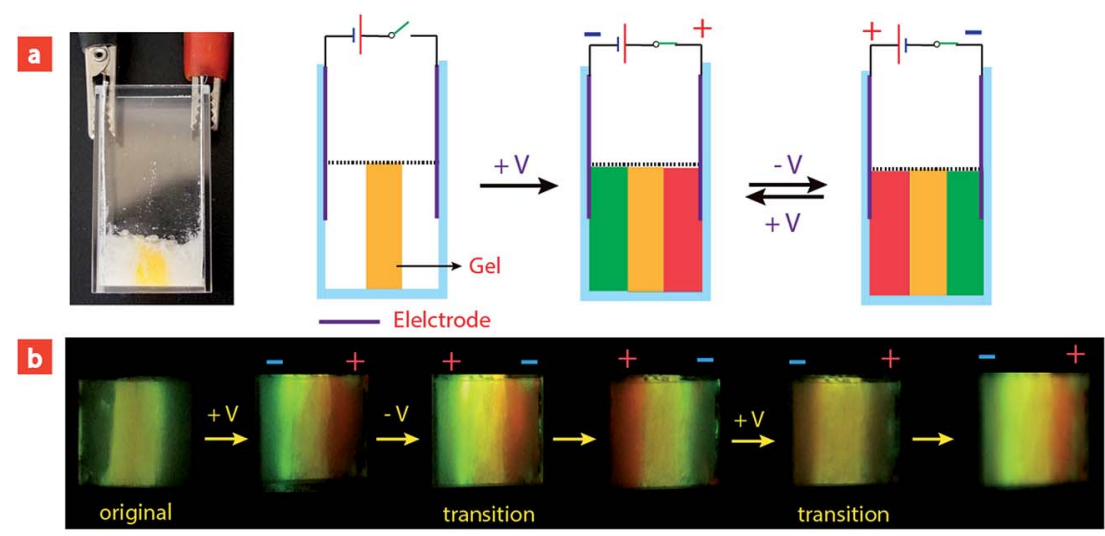

c

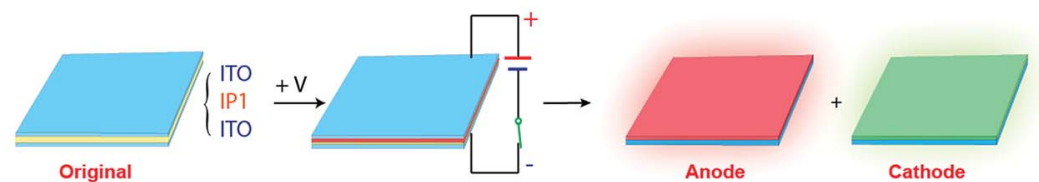

d
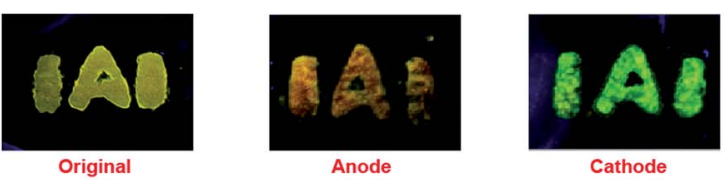

Cathode
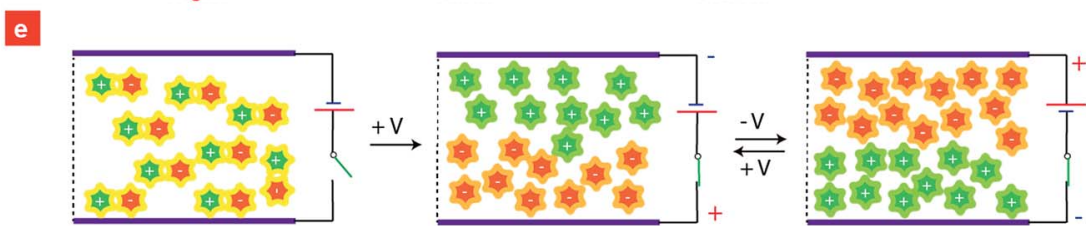

Fig. 4 (a and c) The schematic diagram of the setup for electrochromic luminescence experiments. (b and d) Photographs of electrochromic luminescence experiments using quasi-solid film doped with IP1. (e) Schematic illustration of ion migration under electric stimuli. 
Furthermore, color-tunable electrochromic luminescence has been realized by using other IPs (IP2-IP6, Fig. 3). For example, the emission color of IP2 can be changed from yellow to blue at the anode and orange at the cathode. For IP3, the emission color at the anode changed from red to blue, while that near the cathode remained red because of efficient energy transfer. For IP4, the emission color changed from green to blue at the anode, and remained green near the cathode. For IP5, the emission color at the cathode changed from yellow to orange, and that near the anode remained yellow. For IP6, the emission color at the cathode changed from orange to blue-green, and that near the anode remained orange.

Based on the above results, we further realized the electrochromic luminescence in a quasi-solid state. A device with a simple sandwiched structure, in which a quasi-solid film was coated between two Pt electrodes, has been fabricated. The yellow-emitting quasi-solid film was prepared by mixing ion pair IP1 with DMSO and $\mathrm{SiO}_{2}$ particles (300-400 mesh). The IPs are able to freely migrate within the inorganic network channels of the $\mathrm{SiO}_{2}$ skeleton and the phosphorescence properties of IPs would not be affected by the presence of $\mathrm{SiO}_{2}$ particles. Under a voltage of $3 \mathrm{~V}$, the luminescent color near the anode changed from yellow to red and that near the cathode was altered to green, which is consistent with the electrochromic luminescence observed in solution. When reversing the direction of the electric field, the emission colors near the two electrodes exchanged within 20 minutes (Fig. S7 $\dagger$ ).

Next, we carried out another experiment to further confirm that the mechanism of electrochromic luminescence is due to the migrations of the ions under an electric field, as shown in Fig. 4a and b. At first, a quasi-solid gel was prepared by adding several drops of DMSO into $\mathrm{SiO}_{2}$ particles and then coated between two Pt electrodes. IP1 was doped into the middle of the gel, which showed a yellow emission. Upon applying a voltage of $3 \mathrm{~V}$ for 10 minutes, green emission color appeared and gradually spread to the cathode. Meanwhile, the red emission color spread to the anode gradually. Next, the direction of the electric field was exchanged, and the emission colors near the two edges were switched. This phenomenon can be repeated. The above results demonstrated that the electrochromic luminescence is induced by the migration of the ions.

Finally, a simple sandwiched structure device, in which a quasi-solid film (about $2 \mathrm{~mm}$ in thickness) doped with IP1 was coated between two ITO electrodes, has been fabricated as shown in Fig. 4c and d. At first, a letter pattern of "IAI" was coated onto the ITO electrodes. The color of the pattern was orange. Then a voltage of $3 \mathrm{~V}$ was applied to the ITO electrodes for about 3-4 seconds. The emission color of the film near the anode changed to red immediately. Meanwhile, a green color appeared near the cathode. This phenomenon can be repeated very well.

\section{Conclusions}

In summary, we have developed a class of tunable emissive materials based on luminescent ion-paired iridium(III) complexes. The photophysical properties of the IPs have been studied in detail. Orange, light yellow and white light-emitting devices were successfully fabricated by coating the polymer films doped with IP6 on commercially available ultraviolet LEDs. Furthermore, a new strategy for the design of electricresponsive materials which display tunable and reversible electrochromic luminescence was presented. Changing the moiety of cationic or anionic iridium(III) complexes moiety can be used to tune the electrochromic luminescence colors of these ion pairs. To demonstrate the potential practical applications, a solid-film electrochromic switch device using IPs, which showed a fast and reversible emission color change, has been fabricated successfully. These results showed that electrochromic luminescent materials based on ion pairs will be promising candidates for applications in optoelectronic fields.

\section{Experimental}

\section{General}

Unless otherwise stated, all starting materials and reagents were purchased from commercial suppliers and were used without further purification. Silica particles (Aerosil 200, $12 \mathrm{~nm}$ ) were purchased from Degussa Company (Evonik Industries AG, Rellinghauser Strabe 1-11, 45128 Essen, Germany). $\mathrm{CH}_{2} \mathrm{Cl}_{2}$, $\mathrm{CH}_{3} \mathrm{CN}$ and $\mathrm{CH}_{3} \mathrm{OH}$ were dried under reflux over $\mathrm{CaH}_{2}$ or sodium for several hours at $70-75{ }^{\circ} \mathrm{C}$, distilled at these conditions and used fresh. NMR spectra were recorded on a Bruker Ultra Shield Plus $400 \mathrm{MHz}$ NMR instrument $\left({ }^{1} \mathrm{H}: 400 \mathrm{MHz},{ }^{13} \mathrm{C}\right.$ $\left\{{ }^{1} \mathrm{H}\right\}: 100 \mathrm{MHz},{ }^{19} \mathrm{~F}\left\{{ }^{1} \mathrm{H}\right\}: 377 \mathrm{MHz}$ ). Chemical shifts (ppm) were reported relative to tetramethylsilane (TMS). Mass spectra were obtained on a Bruker autoflex MALDI-TOF/TOF mass spectrometer and a ESI-MS (LCQ Fleet, Thermo Fisher Scientific). UV-Vis absorption spectra were recorded on a UV-1700 Shimadzu UV-Vis spectrophotometer. The photoluminescence spectra and emission lifetimes were recorded on an Edinburgh FL920 spectrofluorometer system.

\section{Synthesis of 1}

A mixture of 2-bromopyridine (1.03 g, $6.52 \mathrm{mmol}), 2$,4-difluorophenylboronic acid $(0.94 \mathrm{~g}, 5.95 \mathrm{mmol}), \mathrm{Pd}\left(\mathrm{PPh}_{3}\right)_{4}(0.21 \mathrm{~g}$, $0.18 \mathrm{mmol})$ and potassium carbonate $(1.0 \mathrm{~g})$ in toluene $(30.0 \mathrm{~mL}), \mathrm{H}_{2} \mathrm{O}(10.0 \mathrm{~mL})$ and EtOH $(10.0 \mathrm{~mL})$ was stirred for 24 $\mathrm{h}$ at $85{ }^{\circ} \mathrm{C}$ under nitrogen. The reaction mixture was cooled down to room temperature, then $50.0 \mathrm{~mL} \mathrm{H}_{2} \mathrm{O}$ was added, and the solution was extracted with dichloromethane. The organic layer was dried over $\mathrm{Na}_{2} \mathrm{SO}_{4}$, and the solvents were removed in vacuo. The crude material was purified by column chromatography over silica gel (PE $\rightarrow$ PE/EA, $75: 1$ ), yielding the yellow oil. Yield: $1.08 \mathrm{~g}$ (95.0\%).

${ }^{1} \mathrm{H}$ NMR (400 MHz, DMSO- $\left.d_{6}\right): \delta=8.70\left(\mathrm{ddd}, J_{1}=0.8 \mathrm{~Hz}, J_{2}=\right.$ $\left.1.6 \mathrm{~Hz}, J_{3}=4.8 \mathrm{~Hz}, 1 \mathrm{H}\right) ; 7.98\left(\mathrm{dt}, J_{1}=6.8 \mathrm{~Hz}, J_{2}=9.2 \mathrm{~Hz}, 1 \mathrm{H}\right) ; 7.88$ $\left(\mathrm{dt}, J_{1}=1.6 \mathrm{~Hz}, J_{2}=7.6 \mathrm{~Hz}, 1 \mathrm{H}\right) ; 7.74(\mathrm{~m}, 1 \mathrm{H}) ; 7.38$ (ddd, $J_{1}=$ $\left.1.2 \mathrm{~Hz}, J_{2}=4.8 \mathrm{~Hz}, J_{3}=7.6 \mathrm{~Hz}, 1 \mathrm{H}\right) ; 7.35\left(\mathrm{ddd}, J_{1}=2.4 \mathrm{~Hz}, J_{2}=\right.$ $\left.9.2 \mathrm{~Hz}, J_{3}=11.6 \mathrm{~Hz}, 1 \mathrm{H}\right) ; 7.20\left(\mathrm{ddt}, J_{1}=0.8 \mathrm{~Hz}, J_{2}=2.4 \mathrm{~Hz}, J_{3}=\right.$ $8.8 \mathrm{~Hz}, 1 \mathrm{H}) .{ }^{13} \mathrm{C}\left\{{ }^{1} \mathrm{H}\right\} \mathrm{NMR}(100 \mathrm{MHz}, \mathrm{DMSO}): \delta=162.57\left(\mathrm{dd},{ }^{3} J_{\mathrm{C}-\mathrm{F}}\right.$ $\left.=12.3 \mathrm{~Hz},{ }^{1} J_{\mathrm{C}-\mathrm{F}}=247.1 \mathrm{~Hz}\right) ; 159.90\left(\mathrm{dd},{ }^{3} J_{\mathrm{C}-\mathrm{F}}=12.3 \mathrm{~Hz},{ }^{1} J_{\mathrm{C}-\mathrm{F}}\right.$ $=249.6 \mathrm{~Hz}) ; 151.64\left(\mathrm{~d},{ }^{3} J_{\mathrm{C}-\mathrm{F}}=2.5 \mathrm{~Hz}\right), 149.81 ; 136.94 ; 132.23$ 
$\left(\mathrm{dd},{ }^{3} J_{\mathrm{C}-\mathrm{F}}=4.5 \mathrm{~Hz},{ }^{3} J_{\mathrm{C}-\mathrm{F}}=9.8 \mathrm{~Hz}\right) ; 123.93\left(\mathrm{~d},{ }^{3} J_{\mathrm{C}-\mathrm{F}}=8.6 \mathrm{~Hz}\right)$; $123.70\left(\mathrm{~d},{ }^{2} J_{\mathrm{C}-\mathrm{F}}=11.8 \mathrm{~Hz}\right) ; 122.90 ; 112.05\left(\mathrm{~d},{ }^{2} J_{\mathrm{C}-\mathrm{F}}=21.1 \mathrm{~Hz}\right)$; $104.56\left(\mathrm{t},{ }^{2} J_{\mathrm{C}-\mathrm{F}}=27.0 \mathrm{~Hz}\right) .{ }^{19} \mathrm{~F}\left\{{ }^{1} \mathrm{H}\right\} \mathrm{NMR}(376.5 \mathrm{MHz}, \mathrm{DMSO}) \delta=$ $-109.35(\mathrm{~d}, J=8.28 \mathrm{~Hz}) ;-112.826(\mathrm{~d}, J=8.28 \mathrm{~Hz})$. ESI-MS $(\mathrm{m} / \mathrm{z})$ : calcd for $\mathrm{C}_{11} \mathrm{H}_{7} \mathrm{~F}_{2} \mathrm{~N}, 191.05$; found, 191.12 .

\section{Synthesis of 2}

A mixture of 2-(2-pyridyl)benzimidazole (200.0 $\mathrm{mg}, 2.5 \mathrm{mmol}$ ), $n$-hexane $(175.0 \mathrm{mg}, 2.6 \mathrm{mmol})$ and potassium hydroxide $(60.0 \mathrm{mg}$, $2.5 \mathrm{mmol})$ in DMF $(5.0 \mathrm{~mL})$ was heated at room temperature under nitrogen atmosphere for $4 \mathrm{~h}$, and then extracted with $\mathrm{CH}_{2} \mathrm{Cl}_{2}$ and water. The crude product was purified through column chromatography on silica gel ( $\mathrm{PE} \rightarrow \mathrm{PE} / \mathrm{EA}, 30: 1)$ to yield pure product as a colorless oil. Yield: $0.46 \mathrm{mg}(61.0 \%)$.

${ }^{1} \mathrm{H}$ NMR $\left(400 \mathrm{MHz}, \mathrm{CDCl}_{3}\right): \delta=8.67(\mathrm{~d}, J=4.0 \mathrm{~Hz}, 1 \mathrm{H}) ; 8.38$ $(\mathrm{d}, J=8.0 \mathrm{~Hz}, 1 \mathrm{H}) ; 7.85-7.81(\mathrm{~m}, 2 \mathrm{H}) ; 7.44\left(\mathrm{dd}, J_{1}=6.7 \mathrm{~Hz}, J_{2}=\right.$ $2.0 \mathrm{~Hz}, 1 \mathrm{H}) ; 7.35-7.27(\mathrm{~m}, 3 \mathrm{H}) ; 4.81(\mathrm{t}, J=8.0 \mathrm{~Hz}, 3 \mathrm{H}) ; 1.86(\mathrm{dt}, J$ $=15.0 \mathrm{~Hz}, 7.6 \mathrm{~Hz}, 2 \mathrm{H})$; $1.36-1.24(\mathrm{~m}, 6 \mathrm{H}) ; 0.85(\mathrm{t}, J=7.1 \mathrm{~Hz}$, $3 \mathrm{H}) .{ }^{13} \mathrm{C}\left\{{ }^{1} \mathrm{H}\right\} \mathrm{NMR}\left(100 \mathrm{MHz}, \mathrm{CDCl}_{3}, 298 \mathrm{~K}\right): \delta=150.92 ; 150.08$; $148.76 ; 142.81 ; 136.89 ; 136.77 ; 124.82 ; 123.80 ; 123.31 ; 122.60$; $120.21 ; 110.37 ; 45.58 ; 31.47 ; 30.13 ; 26.62 ; 22.64 ; 14.12$. ESI-MS $(\mathrm{m} / \mathrm{z})$ : calcd for $\mathrm{C}_{18} \mathrm{H}_{21} \mathrm{~N}_{3}, 279.17$; found, 279.28 .

\section{Synthesis of 3}

A mixture of 2-aminothiophenol $(4.0 \mathrm{~g})$ and 4-hydroxybenzaldehyde $(4.12 \mathrm{~mL})$ in DMF $(10 \mathrm{~mL})$ was heated to reflux under nitrogen atmosphere at $110{ }^{\circ} \mathrm{C}$ for $72 \mathrm{~h}$. Next, the reaction mixture was cooled down to room temperature, and then the mixture was extracted with $\mathrm{H}_{2} \mathrm{O}$ and ethyl acetate. The solvent was removed under reduced pressure and the product was recrystallized with ethanol.

\section{Synthesis of 4}

A mixture of 3, imidazole (200 mg), tert-butylchlorodiphenylsilane $(2 \mathrm{~mL})$ and DMF $(4.6 \mathrm{~mL})$ in a two-necked flask was heated to reflux under nitrogen atmosphere at $40{ }^{\circ} \mathrm{C}$ for $24 \mathrm{~h}$. Next, the reaction mixture was cooled down to room temperature, and then the mixture was extracted with $\mathrm{H}_{2} \mathrm{O}$ and ethyl acetate. The solvent was removed under reduced pressure and the product was recrystallized with ethanol.

${ }^{1} \mathrm{H}$ NMR $\left(400 \mathrm{MHz}, \mathrm{CDCl}_{3}\right): \delta=7.99(\mathrm{~d}, J=8.0 \mathrm{~Hz}, 1 \mathrm{H})$; 7.867.82 (m, 3H); 7.74-7.72 (m, 4H); 7.47-7.31 (m, 8H); 6.85 (d, $J=$ $8.4 \mathrm{~Hz}, 2 \mathrm{H}) ; 1.12(\mathrm{~s}, 9 \mathrm{H})$. ESI-MS $(\mathrm{m} / \mathrm{z})$ : calcd for $\mathrm{C}_{29} \mathrm{H}_{27} \mathrm{NOSSi}$, 465.17; found, 464.97.

\section{Synthesis of 5}

Water $(56.0 \mathrm{~mL})$, anhydrous ethanol $(112.0 \mathrm{~mL})$ and acetic acid $(112.0 \mathrm{~mL})$ were added into a bottle. Then, iron powder $(13.15 \mathrm{~g}$, $0.235 \mathrm{~mol}$ ) was added and the temperature was adjusted to $75{ }^{\circ} \mathrm{C}$. Lastly, benzaldehyde $(5.0 \mathrm{~g}, 0.033 \mathrm{~mol})$ was poured into the bottle slowly and stirred for $15 \mathrm{~min}$. Then the reaction mixture was cooled down to room temperature, the crude product was filtered and the filtrate was collected, which was then extracted with $\mathrm{CH}_{2} \mathrm{Cl}_{2}$ and water. Next, the organic phase was washed with saturated sodium bicarbonate solution
(300 $\mathrm{mL} \times 3$ times) and deionized water $(300 \mathrm{~mL} \times 3$ times $)$, and then dried over anhydrous magnesium sulfate. The solvent was removed under reduced pressure to afford a yellow oily liquid. Yield: $3.25 \mathrm{~g}(81.0 \%)$.

${ }^{1} \mathrm{H}$ NMR $\left(400 \mathrm{MHz}, \mathrm{CDCl}_{3}\right): \delta=9.81(\mathrm{~d}, J=0.8 \mathrm{~Hz}, 1 \mathrm{H}) ; 7.53$ $\left(\mathrm{dd}, J_{1}=1.6 \mathrm{~Hz}, J_{2}=7.6 \mathrm{~Hz}, 1 \mathrm{H}\right) ; 7.29\left(\mathrm{ddd}, J_{1}=1.6 \mathrm{~Hz}, J_{2}=7.2\right.$ $\mathrm{Hz}, J_{3}=8.4 \mathrm{~Hz} ; 1 \mathrm{H}$ ); 7.10 (brs, 2H); 6.70-6.85 (m, 1H); 6.63 (ddd, $\left.J_{1}=1.2 \mathrm{~Hz}, J_{2}=7.2 \mathrm{~Hz}, J_{3}=8.0 \mathrm{~Hz}, 1 \mathrm{H}\right)$. ESI-MS $(\mathrm{m} / \mathrm{z})$ : calcd for $\mathrm{C}_{7} \mathrm{H}_{7} \mathrm{NO}, 121.06$; found, 120.98 .

\section{Synthesis of 6}

Sodium hydroxide $(1.0 \mathrm{~g})$ was dissolved in anhydrous ethanol $(15.0 \mathrm{~mL})$. To this solution was added $o$-amino-benzaldehyde (600.0 $\mathrm{mg}, 4.96 \mathrm{mmol})$ and 2-acetylthiophene $(688.0 \mathrm{mg}$, $5.46 \mathrm{mmol})$. The reaction mixture was refluxed at $80{ }^{\circ} \mathrm{C}$ with stirring for $12 \mathrm{~h}$. The reaction mixture was cooled down to room temperature and the mixture was extracted with $\mathrm{CH}_{2} \mathrm{Cl}_{2}$, and then the solvent was removed under reduced pressure. Purifying the residue using silica gel column chromatography $\left(\mathrm{CH}_{2} \mathrm{Cl}_{2} / \mathrm{PE}, 1: 10\right)$ gave a white solid. Yield: $835.4 \mathrm{mg}(80.0 \%)$.

${ }^{1} \mathrm{H} \mathrm{NMR}\left(\mathrm{CDCl}_{3}\right): \delta=8.14(\mathrm{~d}, J=8.8 \mathrm{~Hz}, 1 \mathrm{H}) ; 8.09(\mathrm{~d}, J=8.8$ $\mathrm{Hz}, 1 \mathrm{H}) ; 7.79$ (d, $J=8.8 \mathrm{~Hz}, 1 \mathrm{H}) ; 7.76\left(\mathrm{dd}, J_{1}=1.6 \mathrm{~Hz}, J_{2}=8.4\right.$ $\mathrm{Hz}, 1 \mathrm{H}) ; 7.74\left(\mathrm{dd}, J_{1}=0.8 \mathrm{~Hz}, J_{2}=4.0 \mathrm{~Hz}, 1 \mathrm{H}\right) ; 7.69\left(\mathrm{ddd}, J_{1}=1.6\right.$ $\left.\mathrm{Hz}, J_{2}=7.2 \mathrm{~Hz}, J_{3}=8.4 \mathrm{~Hz} ; 1 \mathrm{H}\right) ; 7.49\left(\mathrm{ddd}, J_{1}=1.2 \mathrm{~Hz}, J_{2}=6.8\right.$ $\left.\mathrm{Hz}, J_{3}=8.0 \mathrm{~Hz} ; 1 \mathrm{H}\right) ; 7.47\left(\mathrm{dd}, J_{1}=1.2 \mathrm{~Hz}, J_{2}=5.2 \mathrm{~Hz}, 1 \mathrm{H}\right)$. ESIMS (m/z): calcd for $\mathrm{C}_{13} \mathrm{H}_{9} \mathrm{NS}, 211.05$; found, 211.16.

\section{Synthesis of 7}

Sodium hydroxide (1.0 g) was dissolved in anhydrous ethanol $(15.0 \mathrm{~mL})$. To this solution was added $o$-amino benzaldehyde (600.0 $\mathrm{mg}, 4.96 \mathrm{mmol}$ ) and acetophenone (0.6 mL, $4.28 \mathrm{mmol}$ ). The reaction mixture was refluxed at $80{ }^{\circ} \mathrm{C}$ with stirring for $12 \mathrm{~h}$. The reaction mixture was cooled down to room temperature and extracted with $\mathrm{CH}_{2} \mathrm{Cl}_{2}$, and the solvent was removed under reduced pressure. The crude product was purified using column chromatography on silica gel $\left(\mathrm{CH}_{2} \mathrm{Cl}_{2} / \mathrm{PE}, 1: 10\right)$ to yield the pure product as a white solid. Yield: $686.5 \mathrm{mg}(81.0 \%)$.

${ }^{1} \mathrm{H}$ NMR $\left(\mathrm{CDCl}_{3}\right): \delta=8.23(\mathrm{~d}, J=8.4 \mathrm{~Hz}, 1 \mathrm{H}) ; 8.19-8.16(\mathrm{~m}$, $3 \mathrm{H}) ; 7.89(\mathrm{~d}, J=8.4 \mathrm{~Hz}, 1 \mathrm{H}) ; 7.84\left(\mathrm{dd}, J_{1}=1.2 \mathrm{~Hz}, J_{2}=8.0 \mathrm{~Hz}\right.$, $1 \mathrm{H}) ; 7.74$ (ddd, $\left.J_{1}=1.2 \mathrm{~Hz}, J_{2}=6.8 \mathrm{~Hz}, J_{3}=8.4 \mathrm{~Hz}, 1 \mathrm{H}\right) ; 7.56-$ $7.52(\mathrm{~m}, 3 \mathrm{H}) ; 7.47\left(\mathrm{tt}, J_{1}=2.4 \mathrm{~Hz}, J_{2}=7.2 \mathrm{~Hz}, 1 \mathrm{H}\right)$. ESI-MS $(\mathrm{m} / \mathrm{z})$ : calcd for $\mathrm{C}_{15} \mathrm{H}_{11} \mathrm{~N}, 205.09$; found, 205.18.

\section{Synthesis of $\left[(2 \mathrm{fppy})_{2} \operatorname{Ir}(\mu-\mathrm{Cl})_{2} \operatorname{Ir}(2 \mathrm{fppy})_{2}\right]$}

A mixture of $\mathrm{IrCl}_{3} \cdot 3 \mathrm{H}_{2} \mathrm{O}(200.0 \mathrm{mg}, 0.56 \mathrm{mmol})$ and 2-(2,4difluorophenyl)pyridine (2fppy) (235.8 mg, $0.91 \mathrm{mmol}$ ) in 2ethoxyethanol/water $(8.0 \mathrm{~mL}, 3: 1 \mathrm{v} / \mathrm{v})$ was heated to reflux under nitrogen atmosphere for $24 \mathrm{~h}$. Next, the reaction mixture was cooled down to room temperature, a large amount of water was added into the mixture, which was filtered. Then the residue was dried to give the desired yellow-green powder.

\section{Synthesis of C1Cl}

A mixture of yellow powder of $\left[(2 \mathrm{fppy})_{2} \operatorname{Ir}(\mu-\mathbf{C l})_{2} \operatorname{Ir}(2 \mathrm{fppy})_{2}\right]$ (100.0 $\mathrm{mg}, 0.093 \mathrm{mmol})$ and auxiliary ligand $N$-hexyl-2-(2- 
pyridyl)benzimidazole (2) (52.0 $\mathrm{mg}, 0.186 \mathrm{mmol}$ ) in $\mathrm{MeOH}$ $(3.0 \mathrm{~mL})$ and $\mathrm{CH}_{2} \mathrm{Cl}_{2}(9.0 \mathrm{~mL})$ was stirred for $4 \mathrm{~h}$ at $40{ }^{\circ} \mathrm{C}$. The reaction mixture was cooled down to room temperature and evaporated to dryness. The crude material was purified by column chromatography over silica gel $\left(\mathrm{CH}_{2} \mathrm{Cl}_{2} \rightarrow \mathrm{CH}_{2} \mathrm{Cl}_{2} /\right.$ $\mathrm{MeOH}, 45: 1$ ), yielding the orange-red solid. Yield: $99.6 \mathrm{mg}$ (60.4\%).

${ }^{1} \mathrm{H}$ NMR (400 MHz, DMSO- $\left.d_{6}\right): \delta=8.68(\mathrm{~d}, J=8.4 \mathrm{~Hz}, 2 \mathrm{H})$; $8.38\left(\mathrm{dt}, J_{1}=1.2 \mathrm{~Hz}, J_{2}=8.0 \mathrm{~Hz}, 1 \mathrm{H}\right) ; 8.31(\mathrm{~d}, J=8.4 \mathrm{~Hz}, 1 \mathrm{H})$; $8.21(\mathrm{~d}, J=8.8 \mathrm{~Hz}, 1 \mathrm{H}) ; 8.05-7.94(\mathrm{~m}, 4 \mathrm{H}) ; 7.83\left(\mathrm{dd}, J_{1}=0.8 \mathrm{~Hz}\right.$, $\left.J_{2}=5.6 \mathrm{~Hz}, 1 \mathrm{H}\right) ; 7.76-7.73(\mathrm{~m}, 2 \mathrm{H}) ; 7.47\left(\mathrm{ddd}, J_{1}=0.6 \mathrm{~Hz}, J_{2}=\right.$ $\left.6.4 \mathrm{~Hz}, J_{3}=7.6 \mathrm{~Hz}, 1 \mathrm{H}\right) ; 7.22-7.16(\mathrm{~m}, 3 \mathrm{H}) ; 7.04\left(\mathrm{ddd}, J_{1}=\right.$ $\left.2.4 \mathrm{~Hz}, J_{2}=9.6 \mathrm{~Hz}, J_{3}=12.4 \mathrm{~Hz}, 1 \mathrm{H}\right) ; 6.99\left(\mathrm{ddd}, J_{1}=2.4 \mathrm{~Hz}, J_{2}=\right.$ $\left.9.6 \mathrm{~Hz}, J_{3}=12.4 \mathrm{~Hz}, 1 \mathrm{H}\right) ; 6.25(\mathrm{~d}, J=8.0 \mathrm{~Hz}, 1 \mathrm{H}) ; 5.72\left(\mathrm{dd}, J_{1}=\right.$ $\left.2.4 \mathrm{~Hz}, J_{2}=8.8 \mathrm{~Hz}, 1 \mathrm{H}\right) ; 5.62\left(\mathrm{dd}, J_{1}=2.4 \mathrm{~Hz}, J_{2}=8.8 \mathrm{~Hz}, 1 \mathrm{H}\right)$; 5.02-4.86 (m, 2H); 1.96-1.86 (m, 2H); 1.28-1.16 (m, 6H); $0.77(\mathrm{t}, J$ $=7.2 \mathrm{~Hz}, 3 \mathrm{H}) .{ }^{13} \mathrm{C}\left\{{ }^{1} \mathrm{H}\right\}$ NMR (100 MHz, DMSO): $\delta=162.97$ (dd, $\left.{ }^{3} J_{\mathrm{C}-\mathrm{F}}=12.5 \mathrm{~Hz},{ }^{1} J_{\mathrm{C}-\mathrm{F}}=254.0 \mathrm{~Hz}\right) ; 162.39\left(\mathrm{dd},{ }^{3} J_{\mathrm{C}-\mathrm{F}}=12.5 \mathrm{~Hz}\right.$, $\left.{ }^{1} J_{\mathrm{C}-\mathrm{F}}=253.6 \mathrm{~Hz}\right) ; 162.81\left(\mathrm{~d},{ }^{3} J_{\mathrm{C}-\mathrm{F}}=6.6 \mathrm{~Hz}\right) ; 160.85\left(\mathrm{dd},{ }^{3} J_{\mathrm{C}-\mathrm{F}}=\right.$ $\left.13.7 \mathrm{~Hz},{ }^{1} J_{\mathrm{C}-\mathrm{F}}=259.0 \mathrm{~Hz}\right) ; 160.51\left(\mathrm{dd},{ }^{3} J_{\mathrm{C}-\mathrm{F}}=12.4 \mathrm{~Hz},{ }^{1} J_{\mathrm{C}-\mathrm{F}}=\right.$ $257.0 \mathrm{~Hz}) ; 155.56$ (d, $\left.{ }^{3} J_{\mathrm{C}-\mathrm{F}}=6.2 \mathrm{~Hz}\right) ; 152.01 ; 151.93 ; 151.92$; $151.68 ; 150.23 ; 149.81 ; 146.16 ; 140.63 ; 139.92 ; 139.73 ; 138.39$; 136.37; 129.10; 128.27 (dd, $\left.J_{1}=2.4 \mathrm{~Hz}, J_{2}=4.1 \mathrm{~Hz}\right) ; 127.86$; 126.18; 126.13; 125.92; 125.35; 124.42 (d, $J=11.1 \mathrm{~Hz}) ; 123.35$ (d, $J=18.3 \mathrm{~Hz}) ; 122.96(\mathrm{~d}, J=19.6 \mathrm{~Hz}) ; 116.17 ; 113.73(\mathrm{~d}, J=$ $16.7 \mathrm{~Hz}) ; 113.10 ; 113.16(\mathrm{~d}, J=15.8 \mathrm{~Hz}) ; 99.06\left(\mathrm{t},{ }^{2} J_{\mathrm{C}-\mathrm{F}}=\right.$ $27.1 \mathrm{~Hz}) ; 98.84\left(\mathrm{t},{ }^{2} J_{\mathrm{C}-\mathrm{F}}=27.1 \mathrm{~Hz}\right) ; 45.49 ; 30.78 ; 29.14 ; 25.49$; 21.94; 13.79. ${ }^{19} \mathrm{~F}\left\{{ }^{1} \mathrm{H}\right\} \operatorname{NMR}(376.5 \mathrm{MHz}, \mathrm{DMSO}): \delta=-106.49(\mathrm{~d}, J$ $=10.17 \mathrm{~Hz}) ;-106.91(\mathrm{~d}, J=10.54 \mathrm{~Hz}) ;-108.61(\mathrm{~d}, J=$ $10.54 \mathrm{~Hz}$ ); -109.12 (d, $J=10.17 \mathrm{~Hz}$ ). MALDI-TOF-MS $(\mathrm{m} / \mathrm{z})$ : calcd for $\mathrm{C}_{40} \mathrm{H}_{33} \mathrm{IrF}_{4} \mathrm{~N}_{5} \mathrm{Cl}, 887.20$; found, $852.06\left(\mathrm{M}-\mathrm{PF}_{6}\right)^{+}$. Anal. calcd, C 54.14, H 3.75, N 7.89; found, C 54.19, H 3.81, N 7.92 .

\section{Synthesis of $\left[(\mathrm{ppy})_{2} \operatorname{Ir}(\mu-\mathrm{Cl})_{2} \operatorname{Ir}(\mathrm{ppy})_{2}\right]$}

A mixture of $\mathrm{IrCl}_{3} \cdot 3 \mathrm{H}_{2} \mathrm{O}(200.0 \mathrm{mg}, 0.56 \mathrm{mmol})$ and 2-phenylpyridine (ppy) (173.8 $\mathrm{mg}, 0.16 \mathrm{mmol})$ in 2-ethoxyethanol/water $(8.0 \mathrm{~mL}, 3: 1 \mathrm{v} / \mathrm{v})$ was heated to reflux under nitrogen atmosphere for $24 \mathrm{~h}$. Next, the reaction mixture was cooled down to room temperature, a large amount of water was added into the mixture, which was filtered. Then the residue was dried to give the desired yellow powder. Yield: $353.8 \mathrm{mg}$ (59.0\%).

\section{Synthesis of C2Cl}

A mixture of yellow powder of $\left[(\mathbf{p p y})_{2} \operatorname{Ir}(\boldsymbol{\mu}-\mathbf{C l})_{2} \mathbf{I r}(\mathbf{p p y})_{2}\right]$ (100.0 mg, $0.093 \mathrm{mmol}$ ) and auxiliary ligand 2,2-dipyridyl (dpy) (29.0 mg, $0.186 \mathrm{mmol})$ in $\mathrm{MeOH}(3.0 \mathrm{~mL})$ and $\mathrm{CH}_{2} \mathrm{Cl}_{2}(9.0 \mathrm{~mL})$ was stirred for $4 \mathrm{~h}$ at $40{ }^{\circ} \mathrm{C}$. The reaction mixture was then cooled to room temperature and evaporated to dryness. The crude material was purified by column chromatography over silica gel $\left(\mathrm{CH}_{2} \mathrm{Cl}_{2} \rightarrow \mathrm{CH}_{2} \mathrm{Cl}_{2} / \mathrm{MeOH}, 45: 1\right)$, yielding the orangered solid. Yield: $41.9 \mathrm{mg}(65.4 \%)$.

${ }^{1} \mathrm{H}$ NMR (400 MHz, DMSO- $\left.d_{6}\right): \delta=8.90(\mathrm{~d}, J=8.4 \mathrm{~Hz}, 2 \mathrm{H})$; 8.29-8.25 (m, 4H); 7.96-7.91 (m, 4H); $7.87\left(\mathrm{dd}, J_{1}=0.8 \mathrm{~Hz}, J_{2}=\right.$ $5.2 \mathrm{~Hz}, 2 \mathrm{H}) ; 7.69\left(\mathrm{ddd}, J_{1}=0.8 \mathrm{~Hz}, J_{2}=5.2 \mathrm{~Hz}, J_{3}=6.4 \mathrm{~Hz}, 2 \mathrm{H}\right)$; $7.61(\mathrm{~d}, J=5.2 \mathrm{~Hz}, 2 \mathrm{H}) ; 7.16\left(\mathrm{ddd}, J_{1}=1.2 \mathrm{~Hz}, J_{2}=5.6 \mathrm{~Hz}, J_{3}=\right.$
$7.2 \mathrm{~Hz}, 2 \mathrm{H}) ; 7.02\left(\mathrm{dt}, J_{1}=1.2 \mathrm{~Hz}, J_{2}=8.0 \mathrm{~Hz}, 2 \mathrm{H}\right) ; 6.90\left(\mathrm{dt}, J_{1}=\right.$ $\left.1.2 \mathrm{~Hz}, J_{2}=7.6 \mathrm{~Hz}, 2 \mathrm{H}\right) ; 6.19\left(\mathrm{dd}, J_{1}=0.8 \mathrm{~Hz}, J_{2}=7.6 \mathrm{~Hz}, 2 \mathrm{H}\right)$. ${ }^{13} \mathrm{C}\left\{{ }^{1} \mathrm{H}\right\}$ NMR $\left(100 \mathrm{MHz}, \mathrm{DMSO}-d_{6}\right): \delta=166.86 ; 155.392 ; 150.49$; $149.87 ; 148.91 ; 143.84 ; 139.75 ; 138.85 ; 131.12 ; 130.31 ; 128.73$; $125.14 ; 125.07 ; 123.99 ; 122.36 ; 120.11$. MALDI-TOF-MS $(\mathrm{m} / \mathrm{z})$ : calcd for $\mathrm{C}_{32} \mathrm{H}_{24} \mathrm{IrN}_{4} \mathrm{Cl}$, 692.13; found, $656.99\left(\mathrm{M}-\mathrm{PF}_{6}\right)^{+}$. Anal. calcd, C 55.52, H 3.49, N 8.09; found, C 55.07, H 3.90, N 7.98.

\section{Synthesis of $n-\mathrm{Bu}_{4} \mathrm{NA} 2$}

The complex $\left[\operatorname{Ir}(\mathrm{ppy})_{2}(\mathrm{CN})_{2}\right] \mathrm{TBA}$, where TBA is the tetrabutylammonium ion, was prepared according to the literature procedure, with some modifications. ${ }^{39}$ The dimeric iridium(III) complex $\left[(\mathbf{p p y})_{2} \mathbf{I r}(\boldsymbol{\mu}-\mathbf{C l})_{2} \mathbf{I r}(\mathbf{p p y})_{2}\right](200.0 \mathrm{mg})$ was dissolved in $30.0 \mathrm{~mL}$ of dichloromethane solvent under nitrogen. To this solution was added tetrabutylammonium cyanide $(100.0 \mathrm{mg})$ ligand. The reaction mixture was refluxed with stirring for $8 \mathrm{~h}$. The reaction mixture was cooled down to room temperature, and then the solution was washed three times with distilled $\mathrm{H}_{2} \mathrm{O}$, and extracted with dichloromethane. The organic layer was dried over $\mathrm{Na}_{2} \mathrm{SO}_{4}$, and the solvents were removed in vacuo. The crude material was purified by column chromatography over silica gel $\left(\mathrm{CH}_{2} \mathrm{Cl}_{2} \rightarrow \mathrm{CH}_{2} \mathrm{Cl}_{2} / \mathrm{MeOH}, 50: 1\right)$, yielding the green solid. Yield: $114.9 \mathrm{mg}(77.5 \%)$.

${ }^{1} \mathrm{H}$ NMR (400 MHz, DMSO- $\left.d_{6}\right): \delta=9.52\left(\mathrm{dd}, J_{1}=0.8 \mathrm{~Hz}, J_{2}=\right.$ $6.0 \mathrm{~Hz}, 2 \mathrm{H}) ; 8.07(\mathrm{~d}, J=8.4 \mathrm{~Hz}, 2 \mathrm{H}) ; 7.89\left(\mathrm{dt}, J_{1}=1.6 \mathrm{~Hz}, J_{2}=7.6\right.$ $\mathrm{Hz}, 2 \mathrm{H}) ; 7.66(\mathrm{~d}, J=7.6 \mathrm{~Hz}, 2 \mathrm{H}) ; 7.31\left(\mathrm{dt}, J_{1}=5.6 \mathrm{~Hz}, J_{2}=7.2 \mathrm{~Hz}\right.$, $2 \mathrm{H}) ; 6.73\left(\mathrm{dt}, J_{1}=1.2 \mathrm{~Hz}, J_{2}=6.8 \mathrm{~Hz}, 2 \mathrm{H}\right) ; 6.61\left(\mathrm{dt}, J_{1}=1.2 \mathrm{~Hz}, J_{2}\right.$ $=7.2 \mathrm{~Hz}, 2 \mathrm{H}) ; 6.08\left(\mathrm{dd}, J_{1}=1.2 \mathrm{~Hz}, J_{2}=7.6 \mathrm{~Hz}, 2 \mathrm{H}\right) ; 3.17-3.13$ (m, 8H); 1.60-1.52 (m, 8H); 1.34-1.25 (m, 8H); $0.93(\mathrm{t}, J=7.6 \mathrm{~Hz}$, $12 \mathrm{H}) .{ }^{13} \mathrm{C}\left\{{ }^{1} \mathrm{H}\right\}$ NMR (100 MHz, DMSO- $\left.d_{6}\right): \delta=168.02 ; 163.78$; $153.48 ; 144.55 ; 136.42 ; 131.48 ; 130.88 ; 128.50 ; 123.81 ; 122.74$; $120.24 ; 119.14 ; 57.71 ; 23.21 ; 19.36 ; 13.64$. MALDI-TOF-MS, ESIMS $(m / z)$ : calcd for $\mathrm{C}_{40} \mathrm{H}_{52} \mathrm{IrN}_{5}, 795.38$; found, $553.17(\mathrm{M}-n$ $\left.\mathrm{Bu}_{4} \mathrm{~N}\right)^{-}, 242.42\left(n-\mathrm{Bu}_{4} \mathrm{~N}\right)^{+}$. Anal. calcd, C 60.57, H 6.49, N 8.56; found, C 60.42, H 6.59, N 8.81.

\section{Synthesis of $\left[(\text { thq })_{2} \operatorname{Ir}(\mu-\mathrm{Cl})_{2} \operatorname{Ir}(\operatorname{thq})_{2}\right]$}

A mixture of $\mathrm{IrCl}_{3} \cdot 3 \mathrm{H}_{2} \mathrm{O}(385.0 \mathrm{mg}, 1.10 \mathrm{mmol})$ and 2-(thiophenyl)quinoline $(500.2 \mathrm{mg}, 2.37 \mathrm{mmol})$ in 2-ethoxyethanol/ water $(8.0 \mathrm{~mL}, 3: 1 \mathrm{v} / \mathrm{v})$ was heated to reflux under nitrogen atmosphere for $24 \mathrm{~h}$. Next, the reaction mixture was cooled down to room temperature and a large amount of water was added into the mixture. The mixture was filtered. Then the residue was dried to give the desired red powder. Yield: 650.8 $\mathrm{mg}(85.0 \%)$.

\section{Synthesis of $\boldsymbol{n}$-Bu $\mathbf{B u}_{4} \mathrm{NA1}$}

The dimeric iridium(III) complex $\left[(\text { thq })_{2} \mathbf{I r}(\boldsymbol{\mu}-\mathbf{C l})_{2} \mathbf{I r}(\mathbf{t h q})_{2}\right]$ (200.0 $\mathrm{mg}, 0.15 \mathrm{mmol}$ ) and tetrabutylammonium cyanide (495.7 $\mathrm{mg}, 1.85 \mathrm{mmol}$ ) ligand were dissolved in $30.0 \mathrm{~mL}$ of dichloromethane solvent under nitrogen. The reaction mixture was refluxed with stirring for $8 \mathrm{~h}$. Then the mixture was cooled to room temperature and extracted with $\mathrm{CH}_{2} \mathrm{Cl}_{2}$ and water. The crude product was purified through column chromatography on silica gel $\left(\mathrm{CH}_{2} \mathrm{Cl}_{2} \rightarrow \mathrm{CH}_{2} \mathrm{Cl}_{2} / \mathrm{MeOH}, 50: 1\right)$ to give the pure product as a red solid. Yield: $85.6 \mathrm{mg}(61.0 \%)$. 
${ }^{1} \mathrm{H}$ NMR $\left(400 \mathrm{MHz}, \mathrm{CDCl}_{3}\right): \delta=9.99(\mathrm{~d}, J=9.2 \mathrm{~Hz}, 2 \mathrm{H}) ; 7.97$ $(\mathrm{d}, J=8.4 \mathrm{~Hz}, 2 \mathrm{H}) ; 7.68-7.65(\mathrm{~m}, 4 \mathrm{H}) ; 7.60(\mathrm{~d}, J=8.4 \mathrm{~Hz}, 2 \mathrm{H})$; 7.42 (t, $J=7.2 \mathrm{~Hz}, 2 \mathrm{H}) ; 7.03(\mathrm{~d}, J=4.4 \mathrm{~Hz}, 2 \mathrm{H}) ; 6.09$ (d, $J=$ $4.4 \mathrm{~Hz}, 2 \mathrm{H})$; 3.11-3.07 (m, 8H); 1.47-1.39 (m, 8H); 1.11-1.06 (m, $8 \mathrm{H}) ; 0.77$ (t, $J=7.6 \mathrm{~Hz}, 12 \mathrm{H}) .{ }^{13} \mathrm{C}\left\{{ }^{1} \mathrm{H}\right\} \mathrm{NMR}\left(100 \mathrm{MHz}, \mathrm{CDCl}_{3}\right)$ : $\delta=170.56 ; 167.67 ; 150.11 ; 141.51 ; 137.76 ; 133.34 ; 131.12$; $130.42 ; 128.95 ; 127.68 ; 125.76 ; 124.71 ; 117.47 ; 58.48 ; 23.80$; 19.47; 13.59. MALDI-TOF-MS, ESI-MS $(\mathrm{m} / \mathrm{z})$ : calcd for $\mathrm{C}_{44} \mathrm{H}_{52} \mathrm{IrN}_{5} \mathrm{~S}_{2}$, 907.33; found, $665.17\left(\mathrm{M}-n-\mathrm{Bu}_{4} \mathrm{~N}\right)^{-}, 242.42(n-$ $\left.\mathrm{Bu}_{4} \mathrm{~N}\right)^{+}$. Anal. calcd, C 58.25, H 5.78, N 7.72; found, C 58.36, H 5.89, N 7.61 .

\section{Synthesis of $\left[(\mathrm{phq})_{2} \operatorname{Ir}(\mu-\mathrm{Cl})_{2} \operatorname{Ir}(\mathrm{phq})_{2}\right]$}

A mixture of $\operatorname{IrCl}_{3} \cdot 3 \mathrm{H}_{2} \mathrm{O}(385.0 \mathrm{mg}, 1.10 \mathrm{mmol})$ and 2-phenylquinoline (phq) $(500.5 \mathrm{mg}, 2.37 \mathrm{mmol})$ in 2-ethoxyethanol/water $(8.0 \mathrm{~mL}, 3: 1 \mathrm{v} / \mathrm{v})$ was heated to reflux under nitrogen atmosphere for $24 \mathrm{~h}$. Next, the reaction mixture was cooled down to room temperature and a large amount of water was added into the mixture. The mixture was filtered. Then the residue was dried to give the desired red powder. Yield: $600.5 \mathrm{mg}(77.1 \%)$.

\section{Synthesis of C3Cl}

A mixture of yellow powder of $\left[(\mathbf{p h q})_{2} \operatorname{Ir}(\mu-\mathbf{C l})_{2} \operatorname{Ir}(\mathbf{p h q})_{2}\right]$ (100.0 $\mathrm{mg}, 0.093 \mathrm{mmol}$ ) and auxiliary ligand 2,2'-biquinoline (bql) $(52.0 \mathrm{mg}, 0.20 \mathrm{mmol})$ in $\mathrm{MeOH}(3 \mathrm{~mL})$ and $\mathrm{CH}_{2} \mathrm{Cl}_{2}(9 \mathrm{~mL})$ was stirred for $4 \mathrm{~h}$ at $40{ }^{\circ} \mathrm{C}$. The reaction mixture was cooled down to room temperature and then evaporated to dryness. The crude material was purified by column chromatography over silica gel $\left(\mathrm{CH}_{2} \mathrm{Cl}_{2} \rightarrow \mathrm{CH}_{2} \mathrm{Cl}_{2} / \mathrm{MeOH}, 45: 1\right)$, yielding the orangered solid. Yield: $41.0 \mathrm{mg}(44.8 \%)$.

${ }^{1} \mathrm{H}$ NMR (400 MHz, DMSO- $\left.d_{6}\right): \delta=8.71(\mathrm{~d}, J=8.8 \mathrm{~Hz}, 2 \mathrm{H})$; $8.49(\mathrm{~d}, J=8.8 \mathrm{~Hz}, 2 \mathrm{H}) ; 8.31(\mathrm{~d}, J=8.8 \mathrm{~Hz}, 2 \mathrm{H}) ; 8.20(\mathrm{~d}, J=8.8$ $\mathrm{Hz}, 2 \mathrm{H}) ; 8.06$ (d, $J=8.8 \mathrm{~Hz}, 2 \mathrm{H}) ; 7.96$ (d, $J=8.0 \mathrm{~Hz}, 2 \mathrm{H}) ; 7.91$ (d, $J=8.0 \mathrm{~Hz}, 2 \mathrm{H}) ; 7.56(\mathrm{t}, J=7.6 \mathrm{~Hz}, 2 \mathrm{H}) ; 7.51(\mathrm{~d}, J=8.8 \mathrm{~Hz}, 2 \mathrm{H})$; $7.43-7.37(\mathrm{~m}, 4 \mathrm{H}) ; 7.09(\mathrm{t}, J=8.0 \mathrm{~Hz}, 2 \mathrm{H}) ; 7.01(\mathrm{t}, J=7.2 \mathrm{~Hz}, 2 \mathrm{H})$; 6.86-6.81 (m, 4H); $6.31(\mathrm{~d}, J=7.2 \mathrm{~Hz}, 2 \mathrm{H}) .{ }^{13} \mathrm{C}\left\{{ }^{1} \mathrm{H}\right\}$ NMR $(100$ MHz, DMSO): $\delta=169.88 ; 159.57 ; 149.09 ; 146.72 ; 145.44 ; 140.99$; $140.59 ; 137.55 ; 131.01 ; 130.96 ; 130.43 ; 129.55 ; 129.43 ; 129.02$; $128.99 ; 128.34 ; 128.24 ; 127.60 ; 127.05 ; 126.46 ; 124.47 ; 123.00$; 121.37; 117.65. MALDI-TOF-MS $(\mathrm{m} / \mathrm{z})$ : calcd for $\mathrm{C}_{48} \mathrm{H}_{32} \mathrm{IrN}_{4} \mathrm{Cl}$, 892.20; found, $857.03\left(\mathrm{M}-\mathrm{PF}_{6}\right)^{+}$. Anal. calcd, C 64.60, H 3.61, N 6.28; found, C 64.50, H 3.52, N 6.54.

\section{Synthesis of $\left[(\mathrm{Si})_{2} \operatorname{Ir}(\mu-\mathrm{Cl})_{2} \operatorname{Ir}(\mathrm{Si})_{2}\right]$}

A mixture of $\mathrm{IrCl}_{3} \cdot 3 \mathrm{H}_{2} \mathrm{O}(200.0 \mathrm{mg}, 0.56 \mathrm{mmol})$ and $7(173.8 \mathrm{mg}$, $0.16 \mathrm{~mL}, 1.12 \mathrm{mmol})$ in 2-ethoxyethanol/water $(8.0 \mathrm{~mL}, 3: 1 \mathrm{v} / \mathrm{v})$ was heated to reflux under nitrogen atmosphere for $24 \mathrm{~h}$. Next, the reaction mixture was cooled down to room temperature, and a large amount of water was added into the mixture, which was then filtered. Then the residue was dried to give the desired yellow powder. Yield: $147.1 \mathrm{mg}(68.0 \%)$.

\section{Synthesis of $\boldsymbol{n}-\mathrm{Bu}_{4} \mathrm{NA3}$}

The dimeric iridium(III) complex $\left[(\mathbf{S i})_{2} \mathbf{I r}(\boldsymbol{\mu}-\mathbf{C l})_{2} \mathbf{I r}(\mathbf{S i})_{2}\right](200.0 \mathrm{mg})$ was dissolved in $30.0 \mathrm{~mL}$ of dichloromethane solvent under nitrogen. To this solution was added tetrabutylammonium cyanide $(100.0 \mathrm{mg})$ ligand. The reaction mixture was refluxed with stirring for $8 \mathrm{~h}$. The mixture was cooled down to room temperature, and then the solution was washed three times with distilled $\mathrm{H}_{2} \mathrm{O}$, and extracted with dichloromethane. The organic layer was dried over $\mathrm{Na}_{2} \mathrm{SO}_{4}$, and the solvents were removed in vacuo. The crude material was purified by column chromatography over silica gel $\left(\mathrm{CH}_{2} \mathrm{Cl}_{2} \rightarrow \mathrm{CH}_{2} \mathrm{Cl}_{2} / \mathrm{MeOH}\right.$, $50: 1)$ to give a green solid. Yield: $115.4 \mathrm{mg}(77.5 \%)$.

${ }^{1} \mathrm{H}$ NMR (400 MHz, DMSO- $\left.d_{6}\right): \delta=9.26\left(\mathrm{dd}, J_{1}=2.4 \mathrm{~Hz}, J_{2}=\right.$ $7.2 \mathrm{~Hz}, 2 \mathrm{H}) ; 8.00\left(\mathrm{dd}, J_{1}=2.4 \mathrm{~Hz}, J_{2}=7.2 \mathrm{~Hz}, 2 \mathrm{H}\right) ; 7.50-7.30(\mathrm{~m}$, $18 \mathrm{H}) ; 7.23-7.19(\mathrm{~m}, 8 \mathrm{H}) ; 6.32\left(\mathrm{dd}, J_{1}=2.4 \mathrm{~Hz}, J_{2}=8.4 \mathrm{~Hz}, 2 \mathrm{H}\right)$; $5.79(\mathrm{~d}, J=2.4 \mathrm{~Hz}, 2 \mathrm{H}) ; 3.18-3.14(\mathrm{~m}, 8 \mathrm{H}) ; 1.61-1.52(\mathrm{~m}, 8 \mathrm{H})$; $1.35-1.26(\mathrm{~m}, 8 \mathrm{H}) ; 0.93(\mathrm{t}, J=7.2 \mathrm{~Hz}, 12 \mathrm{H}) ; 0.75(\mathrm{~s}, 18 \mathrm{H}) .{ }^{13} \mathrm{C}\left\{{ }^{1} \mathrm{H}\right\}$ NMR $\left(100 \mathrm{MHz}, \mathrm{CDCl}_{3}\right): \delta=179.17 ; 166.57 ; 156.95 ; 151.727$; $135.12 ; 135.08 ; 134.67 ; 133.29 ; 133.13 ; 130.65 ; 129.41 ; 129.38$; $127.44 ; 126.67 ; 126.58 ; 124.11 ; 121.43 ; 113.44 ; 58.59 ; 26.53$; 23.77; 19.51; 13.59. MALDI-TOF-MS, ESI-MS $(\mathrm{m} / \mathrm{z})$ : calcd for $\mathrm{C}_{76} \mathrm{H}_{88} \mathrm{IrN}_{5} \mathrm{~S}_{2} \mathrm{O}_{2} \mathrm{Si}_{2}$, 1415.55; found, $1173.67\left(\mathrm{M}-n-\mathrm{Bu}_{4} \mathrm{~N}\right)^{-}$, $242.42\left(n-\mathrm{Bu}_{4} \mathrm{~N}\right)^{+}$. Anal. calcd, C 64.46, H 6.26, N 4.95; found, C 64.21, H 6.39, N 5.11.

\section{Synthesis of IP1}

C1Cl (38.1 $\mathrm{mg}, \quad 0.043 \mathrm{mmol})$ and $\boldsymbol{n}$-Bu $\mathbf{B} \mathbf{N A 1}(39.0 \mathrm{mg}$, $0.043 \mathrm{mmol})$ were added to water $(15.0 \mathrm{~mL})$ and $\mathrm{CH}_{2} \mathrm{Cl}_{2}$ $(15.0 \mathrm{~mL})$. The reaction mixture was stirred for $1 \mathrm{~h}$ at room temperature and then extracted with deionized water. The combined organic extracts were concentrated by rotary evaporation. The resulting solid was washed with $n$-hexane to afford IP1 as a red solid. Yield: $39.6 \mathrm{mg}(60.7 \%)$.

${ }^{1} \mathrm{H}$ NMR (400 MHz, DMSO- $\left.d_{6}\right): \delta=9.90(\mathrm{~d}, J=8.8 \mathrm{~Hz}, 2 \mathrm{H}$ ); $8.64(\mathrm{~d}, J=8.4 \mathrm{~Hz}, 2 \mathrm{H}) ; 8.34-8.29(\mathrm{~m}, 3 \mathrm{H}) ; 8.21$ (d, $J=8.8 \mathrm{~Hz}$, $1 \mathrm{H}) ; 8.03-7.91(\mathrm{~m}, 6 \mathrm{H}) ; 7.81(\mathrm{~d}, J=5.2 \mathrm{~Hz}, 1 \mathrm{H}) ; 7.72-7.67(\mathrm{~m}$, $6 \mathrm{H}) ; 7.56(\mathrm{t}, J=6.8 \mathrm{~Hz}, 1 \mathrm{H}) ; 7.46(\mathrm{t}, J=8.0 \mathrm{~Hz}, 1 \mathrm{H}) ; 7.39-7.35(\mathrm{~m}$, $1 \mathrm{H}) ; 7.23-7.15(\mathrm{~m}, 5 \mathrm{H}) ; 7.02\left(\mathrm{ddd}, J_{1}=2.0 \mathrm{~Hz}, J_{2}=9.2 \mathrm{~Hz}, J_{3}=\right.$ $12.0 \mathrm{~Hz}, 1 \mathrm{H}) ; 6.96\left(\mathrm{ddd}, J_{1}=2.4 \mathrm{~Hz}, J_{2}=9.6 \mathrm{~Hz}, J_{3}=12.4 \mathrm{~Hz}\right.$, $1 \mathrm{H}) ; 6.24(\mathrm{~d}, J=8.4 \mathrm{~Hz}, 1 \mathrm{H}) ; 5.71(\mathrm{~d}, J=4.8 \mathrm{~Hz}, 2 \mathrm{H}) ; 5.61\left(\mathrm{dd}, J_{1}\right.$ $\left.=2.4 \mathrm{~Hz}, J_{2}=8.4 \mathrm{~Hz}, 1 \mathrm{H}\right) ; 4.97-4.84(\mathrm{~m}, 2 \mathrm{H}) ; 1.94-1.86(\mathrm{~m}, 2 \mathrm{H})$; 1.25-1.21 (m, 6H); $0.75(\mathrm{t}, J=6.8 \mathrm{~Hz}, 3 \mathrm{H}) .{ }^{19} \mathrm{~F}\left\{{ }^{1} \mathrm{H}\right\}$ NMR $(376.5$ MHz, DMSO): $\delta=-106.49$ (d, $J=10.17 \mathrm{~Hz}) ;-106.91(\mathrm{~d}, J=$ $10.54 \mathrm{~Hz}$ ); -108.61 (d, $J=10.54 \mathrm{~Hz}$ ); -109 (d, $J=10.17 \mathrm{~Hz}$ ). Because of the asymmetry of the ancillary ligand in $\mathbf{C 1}$, the two $\mathrm{C}^{\wedge} \mathrm{N}$ ligands are non-chemically equivalent. In addition, a coupling process exists between the fluorine nucleus and carbon nucleus, and we did not obtain the ${ }^{13} \mathrm{C}\left\{{ }^{1} \mathrm{H}\right\}$ NMR of IP1. MALDI-TOF-MS, ESI-MS $(\mathrm{m} / \mathrm{z})$ : calcd for $\mathrm{C}_{68} \mathrm{H}_{49} \mathrm{Ir}_{2} \mathrm{~F}_{4} \mathrm{~N}_{9} \mathrm{~S}_{2}$, 1517.27; found, $665.08\left(\mathrm{~A}^{-}\right)$, $852.11\left(\mathrm{C1}^{+}\right)$. Anal. calcd, C 53.85, H 3.26, N 8.31; found, C 53.63, H 3.09, N 8.07.

\section{Synthesis of IP2}

C2Cl (29.7 $\mathrm{mg}, 0.043 \mathrm{mmol}$ ) and $\boldsymbol{n}$-Bu $\mathbf{B} \mathbf{N A 2}(34.1 \mathrm{mg}$, $0.043 \mathrm{mmol})$ were added to water $(15.0 \mathrm{~mL})$ and $\mathrm{CH}_{2} \mathrm{Cl}_{2}$ $(15.0 \mathrm{~mL})$. The reaction mixture was stirred for $1 \mathrm{~h}$ at room temperature and then extracted with deionized water. The combined organic extracts were concentrated by rotary 
evaporation. The resulting solid was washed with $n$-hexane to afford IP2 as a yellow solid. Yield: $32.3 \mathrm{mg}(62.3 \%)$.

${ }^{1} \mathrm{H}$ NMR (400 MHz, DMSO- $\left.d_{6}\right): \delta=9.53(\mathrm{~d}, J=5.6 \mathrm{~Hz}, 2 \mathrm{H})$; $8.86(\mathrm{~d}, J=8.4 \mathrm{~Hz}, 2 \mathrm{H}) ; 8.27-8.24(\mathrm{~m}, 4 \mathrm{H}) ; 8.06(\mathrm{~d}, J=8.0 \mathrm{~Hz}$, $2 \mathrm{H}) ; 7.95-7.86(\mathrm{~m}, 8 \mathrm{H}) ; 7.70-7.61(\mathrm{~m}, 6 \mathrm{H}) ; 7.30(\mathrm{t}, J=6.0 \mathrm{~Hz}$, $2 \mathrm{H}) ; 7.15(\mathrm{t}, J=6.8 \mathrm{~Hz}, 2 \mathrm{H}) ; 7.02(\mathrm{t}, J=7.6 \mathrm{~Hz}, 2 \mathrm{H}) ; 6.90(\mathrm{t}, J=$ $7.2 \mathrm{~Hz}, 2 \mathrm{H}) ; 6.72(\mathrm{t}, J=7.2 \mathrm{~Hz}, 2 \mathrm{H}) ; 6.61(\mathrm{t}, J=7.2 \mathrm{~Hz}, 2 \mathrm{H}) ; 6.19$ $(\mathrm{d}, J=7.6 \mathrm{~Hz}, 2 \mathrm{H}) ; 6.08$ (d, $J=7.2 \mathrm{~Hz}, 2 \mathrm{H}) .{ }^{13} \mathrm{C}\left\{{ }^{1} \mathrm{H}\right\}$ NMR $(100$ MHz, DMSO): $\delta=167.93 ; 166.83 ; 163.83 ; 155.36 ; 153.32 ; 150.48$; $149.83 ; 148.88 ; 144.42 ; 143.82 ; 139.69 ; 138.82 ; 136.13 ; 131.08$; $130.76 ; 130.28 ; 128.69 ; 128.29 ; 125.12 ; 125.06 ; 123.97 ; 123.63$; $122.53 ; 122.32 ; 120.08 ; 119.95 ; 118.93$. MALDI-TOF-MS, ESI-MS $(\mathrm{m} / \mathrm{z})$ : calcd for $\mathrm{C}_{56} \mathrm{H}_{40} \mathrm{Ir}_{2} \mathrm{~F}_{4} \mathrm{~N}_{8}, 1210.26$; found, $657.25\left(\mathrm{~A} 2^{-}\right)$, $553.25\left(\mathrm{C} 2^{+}\right)$. Anal. calcd, C 55.61, H 3.33, N 9.27; found, C 55.20, H 3.39, N 8.91.

\section{Synthesis of IP3}

C3Cl (40.1 mg, $0.045 \mathrm{mmol}$ ) and $\boldsymbol{n}$-Bu $\mathbf{B u}_{4} \mathbf{N A 2}(35.7 \mathrm{mg}, 0.045$ $\mathrm{mmol})$ were added to water $(15.0 \mathrm{~mL})$ and $\mathrm{CH}_{2} \mathrm{Cl}_{2}(15.0 \mathrm{~mL})$. The reaction mixture was stirred for $1 \mathrm{~h}$ at room temperature and then extracted with deionized water. The combined organic extracts were concentrated by rotary evaporation. The resulting solid was washed with $n$-hexane to afford IP3 as a red solid. Yield: $35.6 \mathrm{mg}$ (56.2\%).

${ }^{1} \mathrm{H}$ NMR (400 MHz, DMSO- $\left.d_{6}\right): \delta=9.51(\mathrm{~d}, J=5.2 \mathrm{~Hz}, 2 \mathrm{H})$; $8.70(\mathrm{~d}, J=8.8 \mathrm{~Hz}, 2 \mathrm{H}) ; 8.47(\mathrm{~d}, J=8.8 \mathrm{~Hz}, 2 \mathrm{H}) ; 8.30(\mathrm{~d}, J=8.8$ $\mathrm{Hz}, 2 \mathrm{H}) ; 8.19$ (d, $J=8.8 \mathrm{~Hz}, 2 \mathrm{H}) ; 8.08-8.04(\mathrm{~m}, 4 \mathrm{H}) ; 7.95\left(\mathrm{dd}, J_{1}=\right.$ $\left.0.8 \mathrm{~Hz}, J_{2}=8.0 \mathrm{~Hz}, 2 \mathrm{H}\right) ; 7.91(\mathrm{~d}, J=7.2 \mathrm{~Hz}, 2 \mathrm{H}) ; 7.85\left(\mathrm{ddd}, J_{1}=\right.$ $\left.1.6 \mathrm{~Hz}, J_{2}=6.8 \mathrm{~Hz}, J_{3}=8.4 \mathrm{~Hz}, 2 \mathrm{H}\right) ; 7.66(\mathrm{~d}, J=7.6 \mathrm{~Hz}, 2 \mathrm{H}) ; 7.56$ $\left(\mathrm{ddd}, J_{1}=0.8 \mathrm{~Hz}, J_{2}=6.8 \mathrm{~Hz}, J_{3}=8.0 \mathrm{~Hz} ; 2 \mathrm{H}\right) ; 7.51\left(\mathrm{~d}, J_{1}=8.8\right.$ $\mathrm{Hz}, 2 \mathrm{H}) ; 7.43-7.36(\mathrm{~m}, 4 \mathrm{H}) ; 7.30(\mathrm{t}, J=7.2 \mathrm{~Hz}, 2 \mathrm{H}) ; 7.09$ (ddd, $J_{1}$ $\left.=1.6 \mathrm{~Hz}, J_{2}=6.8 \mathrm{~Hz}, J_{3}=8.8 \mathrm{~Hz} ; 2 \mathrm{H}\right) ; 7.01\left(\mathrm{dt}, J_{1}=1.2 \mathrm{~Hz}, J_{2}=\right.$ $7.2 \mathrm{~Hz}, 2 \mathrm{H}) ; 6.86-6.81(\mathrm{~m}, 4 \mathrm{H}) ; 6.73\left(\mathrm{dt}, J_{1}=1.2 \mathrm{~Hz}, J_{2}=7.6 \mathrm{~Hz}\right.$, $2 \mathrm{H}) ; 6.61\left(\mathrm{dt}, J_{1}=0.8 \mathrm{~Hz}, J_{2} J_{2}=7.2 \mathrm{~Hz}, 2 \mathrm{H}\right) ; 6.30\left(\mathrm{dd}, J_{1}=0.8 \mathrm{~Hz}\right.$, $\left.J_{2}=8.0 \mathrm{~Hz}, 2 \mathrm{H}\right) ; 6.07\left(\mathrm{dd}, J_{1}=0.8 \mathrm{~Hz}, J_{2}=7.6 \mathrm{~Hz}, 2 \mathrm{H}\right) .{ }^{13} \mathrm{C}\left\{{ }^{1} \mathrm{H}\right\}$ NMR (100 MHz, DMSO): $\delta=169.88 ; 168.05 ; 159.57 ; 153.46$; $149.09 ; 146.72 ; 145.44 ; 144.59 ; 140.99 ; 140.59 ; 137.55 ; 136.51$; $131.82 ; 131.01 ; 130.96 ; 130.91 ; 130.43 ; 129.55 ; 129.43 ; 129.02$; $128.99 ; 128.58 ; 128.34 ; 128.24 ; 127.60 ; 127.05 ; 126.46 ; 124.47$; $123.89 ; 123.00 ; 122.83 ; 121.37 ; 120.34 ; 119.22 ; 119.08 ; 117.65$. MALDI-TOF-MS, ESI-MS (m/z): calcd for $\mathrm{C}_{72} \mathrm{H}_{48} \mathrm{Ir}_{2} \mathrm{~N}_{8}, 1410.33$; found, $553.17\left(\mathrm{~A}^{-}\right), 857.11\left(\mathrm{C3}^{+}\right)$. Anal. calcd, C 61.35, H 3.43, N 7.95; found, C 60.97, H 3.79, N 7.86.

\section{Synthesis of IP4}

C1Cl (39.9 mg, $0.045 \mathrm{mmol}$ ) and $\boldsymbol{n}$-Bu $\mathbf{B} \mathbf{N A 2}(35.7 \mathrm{mg}$, $0.045 \mathrm{mmol})$ were added to water $(15.0 \mathrm{~mL})$ and $\mathrm{CH}_{2} \mathrm{Cl}_{2}$ $(15.0 \mathrm{~mL})$. The reaction mixture was stirred for $1 \mathrm{~h}$ at room temperature and then extracted with deionized water. The combined organic extracts were concentrated by rotary evaporation. The resulting solid was washed with $n$-hexane to afford IP4 as a yellow solid. Yield: $29.2 \mathrm{mg}(46.2 \%)$.

${ }^{1} \mathrm{H}$ NMR (400 MHz, DMSO- $\left.d_{6}\right): \delta=9.52(\mathrm{~d}, J=6.0 \mathrm{~Hz}, 2 \mathrm{H})$; $8.66(\mathrm{~d}, J=8.4 \mathrm{~Hz}, 2 \mathrm{H}) ; 8.37-8.34(\mathrm{~m}, 1 \mathrm{H}) ; 8.30(\mathrm{~d}, J=7.6 \mathrm{~Hz}$, $1 \mathrm{H}) ; 8.21$ (d, $J=8.4 \mathrm{~Hz}, 1 \mathrm{H}) ; 8.07-7.86(\mathrm{~m}, 8 \mathrm{H}) ; 7.83(\mathrm{~d}, J=5.6$ $\mathrm{Hz}, 1 \mathrm{H}) ; 7.73-7.71(\mathrm{~m}, 2 \mathrm{H}) ; 7.65(\mathrm{~d}, J=7.6 \mathrm{~Hz}, 2 \mathrm{H}) ; 7.47(\mathrm{t}, J=$
$7.2 \mathrm{~Hz}, 1 \mathrm{H}) ; 7.31-7.15(\mathrm{~m}, 5 \mathrm{H}) ; 7.06-6.96(\mathrm{~m}, 2 \mathrm{H}) ; 6.71\left(\mathrm{dt}, J_{1}=\right.$ $\left.1.2 \mathrm{~Hz}, J_{2}=6.8 \mathrm{~Hz}, 2 \mathrm{H}\right) ; 6.60\left(\mathrm{dt}, J_{1}=0.8 \mathrm{~Hz}, J_{2}=7.2 \mathrm{~Hz}, 2 \mathrm{H}\right)$; $6.25(\mathrm{~d}, J=8.0 \mathrm{~Hz}, 1 \mathrm{H}) ; 6.08\left(\mathrm{dd}, J_{1}=1.2 \mathrm{~Hz}, J_{2}=7.6 \mathrm{~Hz}, 2 \mathrm{H}\right)$; $5.75(\mathrm{~m}, 1 \mathrm{H}) ; 5.62\left(\mathrm{dd}, J_{1}=1.6 \mathrm{~Hz}, J_{2}=8.4 \mathrm{~Hz}, 1 \mathrm{H}\right) ; 5.02-4.84$ (m, 2H); 1.98-1.84 (m, 2H); 1.28-1.19 (m, 6H); $0.77(\mathrm{t}, J=7.2 \mathrm{~Hz}$, $3 \mathrm{H}) .{ }^{19} \mathrm{~F}\left\{{ }^{1} \mathrm{H}\right\}$ NMR (376.5 MHz, DMSO): $\delta=-106.49(\mathrm{~d}, J=10.17$ $\mathrm{Hz}) ;-106.91$ (d, $J=10.54 \mathrm{~Hz}) ;-108.61$ (d, $J=10.54 \mathrm{~Hz}$ ); $-109.12(\mathrm{~d}, J=10.17 \mathrm{~Hz}$ ). Because of the asymmetry of the ancillary ligand in $\mathbf{C 1}$, the two $\mathrm{C}^{\wedge} \mathrm{N}$ ligands are non-chemically equivalent. In addition, a coupling process exists between the fluorine nucleus and carbon nucleus, and there is a low signal to noise ratio in the spectrum of ${ }^{13} \mathrm{C}\left\{{ }^{1} \mathrm{H}\right\}$ NMR. MALDI-TOF-MS, ESI-MS $(\mathrm{m} / \mathrm{z})$ : calcd for $\mathrm{C}_{64} \mathrm{H}_{49} \mathrm{Ir}_{2} \mathrm{~F}_{4} \mathrm{~N}_{9}, 1405.32$; found, 553.08 $\left(\mathrm{A} 2^{-}\right), 852.11\left(\mathrm{C1}^{+}\right)$. Anal. calcd, C 54.73, H 3.52, N 8.98; found, C 54.27, H 3.64, N 8.56.

\section{Synthesis of IP5}

C2Cl (29.7 mg, $0.043 \mathrm{mmol}$ ) and $\boldsymbol{n}$-Bu $\mathbf{B u}_{4} \mathbf{N A 3}$ (60.8 $\mathrm{mg}, 0.043$ $\mathrm{mmol})$ were added to water $(15.0 \mathrm{~mL})$ and $\mathrm{CH}_{2} \mathrm{Cl}_{2}(15.0 \mathrm{~mL})$. The reaction mixture was stirred for $1 \mathrm{~h}$ at room temperature and then extracted with deionized water. The combined organic extracts were concentrated by rotary evaporation. The resulting solid was washed with $n$-hexane to afford IP5 as a yellow solid. Yield: $46.5 \mathrm{mg}$ (59.2\%).

${ }^{1} \mathrm{H}$ NMR $\left(400 \mathrm{MHz}\right.$, DMSO- $\left.d_{6}\right): \delta=9.25\left(\mathrm{dd}, J_{1}=1.2 \mathrm{~Hz}, J_{2}=\right.$ $8.0 \mathrm{~Hz} ; 2 \mathrm{H}) ; 8.87$ (d, $J=8.4 \mathrm{~Hz} ; 2 \mathrm{H}) ; 8.28-8.24$ (m; 4H); 8.01-7.99 $(\mathrm{m} ; 2 \mathrm{H}) ; 7.95-7.91(\mathrm{~m} ; 4 \mathrm{H}) ; 7.86\left(\mathrm{dd}, J_{1}=1.2 \mathrm{~Hz}, J_{2}=5.6 \mathrm{~Hz}\right.$; $2 \mathrm{H}) ; 7.68\left(\mathrm{ddd}, J_{1}=0.8 \mathrm{~Hz}, J_{2}=5.6 \mathrm{~Hz}, J_{3}=6.8 \mathrm{~Hz} ; 2 \mathrm{H}\right) ; 7.61(\mathrm{dd}$, $\left.J_{1}=0.8 \mathrm{~Hz}, J_{2}=5.6 \mathrm{~Hz} ; 2 \mathrm{H}\right) ; 7.50-7.42(\mathrm{~m} ; 6 \mathrm{H}) ; 7.39-7.30(\mathrm{~m}$; $12 \mathrm{H}) ; 7.25-7.19(\mathrm{~m} ; 8 \mathrm{H}) ; 7.15\left(\mathrm{ddd}, J_{1}=1.6 \mathrm{~Hz}, J_{2}=6.0 \mathrm{~Hz}, J_{3}=\right.$ $7.6 \mathrm{~Hz} ; 2 \mathrm{H}) ; 7.02\left(\mathrm{dt}, J_{1}=1.2 \mathrm{~Hz}, J_{2}=7.6 \mathrm{~Hz} ; 2 \mathrm{H}\right) ; 6.90\left(\mathrm{dt}, J_{1}=\right.$ $\left.1.2 \mathrm{~Hz}, J_{2}=7.6 \mathrm{~Hz} ; 2 \mathrm{H}\right) ; 6.32\left(\mathrm{dd}, J_{1}=2.4 \mathrm{~Hz}, J_{2}=8.0 \mathrm{~Hz} ; 2 \mathrm{H}\right)$; $6.19\left(\mathrm{dd}, J_{1}=1.2 \mathrm{~Hz}, J_{2}=7.6 \mathrm{~Hz} ; 2 \mathrm{H}\right) ; 5.78(\mathrm{~d}, J=2.4 \mathrm{~Hz} ; 2 \mathrm{H})$; 0.75 (s; 18H). ${ }^{13} \mathrm{C}\left\{{ }^{1} \mathrm{H}\right\}$ NMR (100 MHz, DMSO): $\delta=178.51$; $166.94 ; 156.32 ; 155.46 ; 151.23 ; 150.57 ; 149.93 ; 148.96 ; 143.92$; $139.82 ; 138.95 ; 134.72 ; 134.68 ; 132.54 ; 132.51 ; 131.20 ; 130.41$; $130.32 ; 129.96 ; 129.36 ; 128.78 ; 127.81 ; 126.80 ; 126.72 ; 125.21$; $125.11 ; 124.93 ; 124.06 ; 123.15 ; 122.85 ; 122.68 ; 122.48 ; 120.19$; $113.15 ; 26.67 ; 19.14$. MALDI-TOF-MS, ESI-MS ( $\mathrm{m} / \mathrm{z})$ : calcd for $\mathrm{C}_{92} \mathrm{H}_{76} \mathrm{Ir}_{2} \mathrm{O}_{2} \mathrm{~N}_{8} \mathrm{~S}_{2} \mathrm{Si}_{2}$, 1830.43; found, 1173.67 (A3 ${ }^{-}$), 657.01 $\left(\mathrm{C}^{+}\right)$. Anal. calcd, C 60.37, H 4.19, N 6.12; found, C 60.11, H 4.36, N 6.30.

IP6 and $\boldsymbol{n}$-Bu $\mathbf{B u}_{\mathbf{4}} \mathbf{N A 4}$ were synthesized according to the literature. ${ }^{39}$

\section{Synthesis of $\boldsymbol{n}-\mathrm{Bu}_{4} \mathrm{NA4}$}

${ }^{1} \mathrm{H}$ NMR (400 MHz, DMSO- $d_{6}$ ): $\delta=9.54\left(\mathrm{dd}, J_{1}=1.2 \mathrm{~Hz}, J_{2}=6.0\right.$ $\mathrm{Hz} ; 2 \mathrm{H}) ; 8.22(\mathrm{~d}, J=8.4 \mathrm{~Hz} ; 2 \mathrm{H}) ; 8.04\left(\mathrm{dt}, J_{1}=1.2 \mathrm{~Hz}, J_{2}=7.6 \mathrm{~Hz}\right.$; $2 \mathrm{H}) ; 7.45$ (ddd, $J_{1}=1.2 \mathrm{~Hz}, J_{2}=6.0 \mathrm{~Hz}, J_{3}=7.0 \mathrm{~Hz} ; 2 \mathrm{H}$ ); 6.61 $\left(\mathrm{ddd}, J_{1}=2.4 \mathrm{~Hz}, J_{2}=9.2 \mathrm{~Hz}, J_{3}=12.0 \mathrm{~Hz} ; 2 \mathrm{H}\right) ; 5.54\left(\mathrm{dd}, J_{1}=2.4\right.$ $\left.\mathrm{Hz}, J_{2}=8.0 \mathrm{~Hz} ; 2 \mathrm{H}\right) ; 3.17-3.13(\mathrm{~m} ; 8 \mathrm{H}) ; 1.59-1.51$ (m; 8H); 1.32$1.24(\mathrm{~m} ; 8 \mathrm{H}) ; 0.92(\mathrm{t} ; 12 \mathrm{H}) .{ }^{13} \mathrm{C}\left\{{ }^{1} \mathrm{H}\right\}$ NMR (100 MHz, DMSO): $\delta=$ $169.79-169.66(\mathrm{~m}) ; 164.36\left(\mathrm{~d},{ }^{3} J_{\mathrm{C}-\mathrm{F}}=7.3 \mathrm{~Hz}\right) ; 162.82\left(\mathrm{dd},{ }^{3} J_{\mathrm{C}-\mathrm{F}}=\right.$ $\left.11.1 \mathrm{~Hz},{ }^{1} J_{\mathrm{C}-\mathrm{F}}=252.6 \mathrm{~Hz}\right) ; 161.12\left(\mathrm{dd},{ }^{3} J_{\mathrm{C}-\mathrm{F}}=11.9 \mathrm{~Hz},{ }^{1} J_{\mathrm{C}-\mathrm{F}}=\right.$ $258.2 \mathrm{~Hz}) ; 154.19 ; 138.044 ; 128.51 ; 128.29\left(\mathrm{t},{ }^{4} J_{\mathrm{C}-\mathrm{F}}=2.2 \mathrm{~Hz}\right)$; $123.86 ; 122.92\left(\mathrm{~d},{ }^{2} J_{\mathrm{C}-\mathrm{F}}=20.3 \mathrm{~Hz}\right) ; 112.36\left(\mathrm{dd},{ }^{4} J_{\mathrm{C}-\mathrm{F}}=2.5 \mathrm{~Hz}\right.$, 
$\left.{ }^{2} J_{\mathrm{C}-\mathrm{F}}=15.2 \mathrm{~Hz}\right) ; 97.02\left(\mathrm{t},{ }^{2} J_{\mathrm{C}-\mathrm{F}}=26.2 \mathrm{~Hz}\right) ; 57.98 ; 23.51 ; 19.65$; 13.95. ${ }^{19} \mathrm{~F}\left\{{ }^{1} \mathrm{H}\right\}$ NMR (376.5 MHz, DMSO): $\delta=-109.91(\mathrm{~d}, J=$ $9.05 \mathrm{~Hz}) ;-110.96(\mathrm{~d}, J=9.42 \mathrm{~Hz})$. MALDI-TOF-MS, ESI-MS $(\mathrm{m} /$ $z$ ): calcd for $\mathrm{C}_{40} \mathrm{H}_{48} \mathrm{IrN}_{5} \mathrm{~F}_{4}, 795.38$; found, $624.41\left(\mathrm{M}-n-\mathrm{Bu}_{4} \mathrm{~N}\right)^{-}$, $242.42\left(n-\mathrm{Bu}_{4} \mathrm{~N}\right)^{+}$. Anal. calcd, C 55.41, H 5.58, N 8.08; found, C 55.72, H 5.70, N 8.21.

\section{Synthesis of IP6}

${ }^{1} \mathrm{H}$ NMR (400 MHz, $\left.\mathrm{CDCl}_{3}\right): \delta=9.74(\mathrm{~d}, J=5.6 \mathrm{~Hz} ; 2 \mathrm{H}) ; 8.95(\mathrm{~d}, J$ $=8.4 \mathrm{~Hz} ; 2 \mathrm{H}) ; 8.06-8.17(\mathrm{~m} ; 4 \mathrm{H}) ; 7.86-7.91(\mathrm{~m} ; 4 \mathrm{H}) ; 7.73(\mathrm{t}, J=$ $8.0 \mathrm{~Hz} ; 2 \mathrm{H}) ; 7.67(\mathrm{~d}, J=8.4 \mathrm{~Hz} ; 2 \mathrm{H}) ; 7.62(\mathrm{t}, J=8.0 \mathrm{~Hz} ; 2 \mathrm{H}) ; 7.47$ $(\mathrm{d}, J=5.6 \mathrm{~Hz} ; 2 \mathrm{H}) ; 7.34(\mathrm{t}, J=6.4 \mathrm{~Hz} ; 2 \mathrm{H}) ; 7.03(\mathrm{t}, J=7.6 \mathrm{~Hz}$; $2 \mathrm{H})$; 6.99-6.90 (m; 6H); 6.28 (d, $J=7.6 \mathrm{~Hz} ; 2 \mathrm{H}) ; 6.18$ (ddd, $J_{1}=$ $\left.2.0 \mathrm{~Hz}, J_{2}=9.2 \mathrm{~Hz}, J_{3}=12.4 \mathrm{~Hz} ; 2 \mathrm{H}\right) ; 5.72\left(\mathrm{dd}, J_{1}=2.4 \mathrm{~Hz}, J_{2}=\right.$ 8.4 Hz; 2H). ${ }^{19} \mathrm{~F}\left\{{ }^{1} \mathrm{H}\right\}$ NMR (376.5 MHz, $\left.\mathrm{CDCl}_{3}\right): \delta=-106.57(\mathrm{~d}, J$ $=10.56 \mathrm{~Hz}) ;-108.8(\mathrm{~d}, J=10.56 \mathrm{~Hz})$. MALDI-TOF-MS $(\mathrm{m} / \mathrm{z})$ : calcd for $\mathrm{C}_{56} \mathrm{H}_{36} \mathrm{Ir}_{2} \mathrm{~F}_{4} \mathrm{~N}_{8}, 1282.23$; found, 624.44 (A4 ${ }^{-}$), 656.99 $\left(\mathrm{C} 2^{+}\right)$. Anal. calcd, C 52.49, H 2.83, N 8.74; found, C 52.09, H 2.66, N 6.49.

\section{Acknowledgements}

We acknowledge financial support from the National Natural Science Foundation of China (61274018), National Program for Support of Top-Notch Young Professionals, Scientific and Technological Innovation Teams of Colleges and Universities in Jiangsu Province (TJ215006), Natural Science Foundation of Jiangsu Province of China (BK20130038), and Priority Academic Program Development of Jiangsu Higher Education Institutions (YX03001).

\section{Notes and references}

1 M. A. Baldo, D. F. O'Brien, Y. You, A. Shoustikov, S. Sibley, M. E. Thompson and S. R. Forrest, Nature, 1998, 395, 151.

2 S. Lamansky, P. Djurovich, D. Murphy, F. A. Razzaq, H. E. Lee, C. Adachi, P. E. Burrows, S. R. Forrest and M. E. Thompson, J. Am. Chem. Soc., 2001, 123, 4304.

3 M. Mydlak, C. Bizzarri, D. Hartmann, W. Sarfert, G. Schmid and L. De Cola, Adv. Funct. Mater., 2010, 20, 1812.

4 H. Sasabe, J. Takamatsu, T. Motoyama, S. Watanabe, G. Wagenblast, N. Langer, O. Molt, E. Fuchs, C. Lennartz and J. Kido, Adv. Mater., 2010, 22, 5003.

5 C. A. Strassert, C. H. Chien, M. D. G. Lopez, D. Kourkoulos, D. Hertel, K. Meerholz and L. De Cola, Angew. Chem., Int. Ed., 2011, 50, 946.

6 S. W. Botchway, M. Charnley, J. W. Haycock, A. W. Parker, D. L. Rochester, J. A. Weinstein and J. A. G. Williams, Proc. Natl. Acad. Sci. U. S. A., 2008, 105, 16071.

7 Z. J. Chen, K. Y. Zhang, X. Tong, Y. H. Liu, C. Y. Hu, S. J. Liu, Q. Yu, Q. Zhao and W. Huang, Adv. Funct. Mater., 2016, 26, 4386.

8 X. B. Zhou, H. Liang, P. F. Jiang, K. Y. Zhang, S. J. Liu, T. S. Yang, Q. Zhao, L. J. Yang, W. Lv, Q. Yu and W. Huang, Adv. Sci., 2016, 3, 1500155.
9 Q. Zhao, C. Q. Zhang, S. J. Liu, Y. H. Liu, K. Y. Zhang, X. B. Zhou, J. Y. Jiang, W. J. Xu, T. S. Yang and W. Huang, Sci. Rep., 2015, 5, 16420.

10 Y. Ma, H. Xu, Y. Zeng, C. L. Ho, C. H. Chui, Q. Zhao, W. Huang and W. Y. Wong, J. Mater. Chem. C, 2015, 3, 66.

11 S. Kesarkar, W. Mroz, M. Penconi, M. Pasini, S. Destri, M. Cazzaniga, D. Ceresoli, P. R. Mussini, C. Baldoli, U. Giovanella and A. Bossi, Angew. Chem., Int. Ed., 2016, 55, 2714.

12 P. R. Beauiuge and J. R. Reynolds, Chem. Rev., 2010, 110, 268. 13 H. J. Yen, C. J. Chen and G. S. Liou, Adv. Funct. Mater., 2013, 23, 5307.

14 L. Ying, C. L. Ho, H. Wu, Y. Cao and W. Y. Wong, Adv. Mater., 2014, 26, 2459.

15 W. Y. Wong and C. L. Ho, Coord. Chem. Rev., 2009, 253, 1709. 16 X. B. Xu, X. L. Yang, J. Zhao, G. J. Zhou and W. Y. Wong, Asian J. Org. Chem., 2015, 4, 394.

17 G. J. Zhou, W. Y. Wong and X. L. Yang, Chem.-Asian J., 2011, 6, 1706.

18 G. J. Zhou, C. L. Ho, W. Y. Wong, Q. Wang, D. G. Ma, L. X. Wang, Z. Y. Lin, T. B. Marder and A. Beeby, Adv. Funct. Mater., 2008, 18, 499.

19 X. L. Yang, X. B. Xu, J. S. Dang, G. J. Zhou, C. L. Ho and W. Y. Wong, Inorg. Chem., 2016, 55, 1720.

20 G. J. Zhou, Q. Wang, X. Z. Wang, C. L. Ho, W. Y. Wong, D. G. Ma, L. X. Wang and Z. Y. Lin, J. Mater. Chem., 2010, 20, 7472 .

21 W. Y. Wong and C. L. Ho, J. Mater. Chem., 2009, 19, 4457.

22 H. Ito, M. Muromoto, S. Kurenuma, S. Ishizaka, N. Kitamura, H. Sato and T. Seki, Nat. Commun., 2013, 4, 2009.

23 T. Mutai, H. Satou and K. Araki, Nat. Mater., 2005, 4, 685.

24 S. Kobatake, S. Takami, H. Muto, T. Ishikawa and M. Irie, Nature, 2007, 446, 778.

25 M. A. Malwitz, S. H. Lim, R. L. W. Morris, D. M. Pham, M. M. Olmstead and A. L. Balch, J. Am. Chem. Soc., 2012, 134, 10885.

$26 \mathrm{~J} . \mathrm{Bu}, \mathrm{K}$. Watanabe, H. Hayasaka and K. Akagi, Nat. Commun., 2014, 5, 3799.

27 M. Han, Y. Tian, Z. Yuan, L. Zhu and B. Ma, Angew. Chem., Int. Ed., 2014, 53, 10908.

28 S. K. Park, I. Cho, J. Gierschner, J. H. Kim, J. H. Kim, J. E. Kwon, O. K. Kwon, D. R. Whang, J. H. Park, B. K. An and S. Y. Park, Angew. Chem., Int. Ed., 2016, 55, 203.

29 Z. Chen, P. C. Hsu, J. Lopez, Y. Z. Li, J. W. F. To, N. Liu, C. Wang, S. C. Andrews, J. Liu, Y. Cui and Z. N. Bao, Nat. Energy., 2016, 1, 15006.

30 L. Shaw, P. Hayoz, Y. Diao, J. A. Reinspach, J. W. F. To, M. F. Toney, R. T. Weitz and Z. N. Bao, ACS Appl. Mater. Interfaces, 2016, 8, 9285.

31 H. H. Chou, A. Nguyen, A. Chortos, J. W. F. To, C. Lu, J. Mei, T. Kurosawa, W. G. Bae, J. B. H. Tok and Z. N. Bao, Nat. Commun., 2015, 6, 8011.

32 A. L. Ayzner, D. Nordlund, D. H. Kim, Z. N. Bao and M. F. Toney, J. Phys. Chem. Lett., 2015, 6, 6.

33 C. Wang, W. Y. Lee, D. Kong, R. Pfattner, G. Schweicher, R. Nakajima, C. Lu, J. Mei, T. H. Lee, H. C. Wu, J. Lopez, Y. Diao, X. Gu, S. Himmelberger, W. Niu, J. R. Matthews, 
M. He, A. Salleo, Y. Nishi and Z. N. Bao, Sci. Rep., 2015, 5, 17849.

34 A. Beneduci, S. Cospito, M. La Deda, L. Veltri and G. Chidichimo, Nat. Commun., 2014, 5, 3105.

35 A. Beneduci, S. Cospito, M. La Deda and G. Chidichimo, Adv. Funct. Mater., 2015, 25, 1240.

36 H. B. Sun, S. J. Liu, W. P. Lin, K. Y. Zhang, W. Lv, X. Huang, F. W. Huo, H. R. Yang, G. Jenkins, Q. Zhao and W. Huang, Nat. Commun., 2014, 5, 3601.

37 W. P. Lin, Q. Zhao, H. B. Sun, K. Y. Zhang, H. R. Yang, Q. Yu, X. H. Zhou, S. Guo, S. J. Liu and W. Huang, Adv. Opt. Mater., 2015, 3, 368.

38 W. P. Lin, Q. Tan, H. Liang, K. Y. Zhang, S. J. Liu, R. Jiang, R. R. Hu, W. J. Xu, Q. Zhao and W. Huang, J. Mater. Chem. C, 2015, 3, 1883 .

39 M. Mauro, K. C. Schuermann, R. Pretot, A. Hafner, P. Mercandelli, A. Sironi and L. De Cola, Angew. Chem., Int. Ed., 2010, 49, 1222.

40 M. Sandroni and E. Z. Colman, Dalton Trans., 2014, 43, 3676.

41 G. Nasr, A. Guerlin, F. Dumur, L. Beouch, E. Dumas, G. Clavier, F. Miomandre, F. Goubard, D. Gigmes, D. Bertin, G. Wantz and C. R. Mayer, Chem. Commun., 2011, 47, 10698.

42 A. Ionescu, E. I. Szerb, Y. J. Yadav, A. M. Talarico, M. Ghedini and N. Godbert, Dalton Trans., 2014, 43, 784.

43 C. Wu, H. F. Chen, K. T. Wong and M. E. Thompson, J. Am. Chem. Soc., 2010, 132, 3133.

44 F. Dumur, G. Nasr, G. Wantz, C. R. Mayer, E. Dumas, A. Guerlin, F. Miomandre, G. Clavier, D. Bertin and D. Gigmes, Org. Electron., 2011, 12, 1683.

45 X. L. Yang, Z. Huang, C. L. Ho, G. J. Zhou, D. R. Whang, C. L. Yao, X. B. Xu, S. Y. Park, C. H. Chui and W. Y. Wong, RSC Adv., 2013, 3, 6553.
46 Y. Ma, H. Liang, Y. Zeng, H. R. Yang, C. L. Ho, W. J. Xu, Q. Zhao, W. Huang and W. Y. Wong, Chem. Sci., 2016, 7, 3338.

47 W. Lv, T. S. Yang, Q. Yu, Q. Zhao, K. Y. Zhang, H. Liang, S. J. Liu, F. Y. Li and W. Huang, Adv. Sci., 2015, 2, 1500107. 48 Q. Zhao, X. B. Zhou, T. Y. Cao, K. Y. Zhang, L. J. Yang, S. J. Liu, H. Liang, H. R. Yang, F. Y. Li and W. Huang, Chem. Sci., 2015, 6, 1825.

49 K. Y. Zhang, J. Zhang, Y. H. Liu, S. J. Liu, P. L. Zhang, Q. Zhao, Y. Tang and W. Huang, Chem. Sci., 2015, 6, 301.

50 S. J. Liu, J. Zhang, D. F. Shen, H. Liang, X. M. Liu, Q. Zhao and W. Huang, Chem. Commun., 2015, 51, 12839.

51 S. J. Liu, H. B. Sun, Y. Ma, S. H. Ye, X. M. Liu, X. H. Zhou, X. Mou, L. H. Wang, Q. Zhao and W. Huang, J. Mater. Chem., 2012, 22, 22167.

52 Q. Yu, K. Y. Zhang, H. Liang, Q. Zhao, T. S. Yang, S. J. Liu, C. Q. Zhang, Z. J. Shi, W. J. Xu and W. Huang, ACS Appl. Mater. Interfaces, 2015, 7, 5462.

53 D. L. Ma, H. Z. He, K. H. Leung, D. S. H. Chan and C. H. Leung, Angew. Chem., Int. Ed., 2013, 52, 7666.

54 L. Lu, D. S. H. Chan, D. W. J. Kwong, H. Z. He, C. H. Leung and D. L. Ma, Chem. Sci., 2014, 5, 4561.

55 D. L. Ma, D. S. H. Chan and C. H. Leung, Acc. Chem. Res., 2014, 47, 3614.

56 H. Yang, J. J. Qian, L. T. Li, Z. G. Zhou, D. Li, H. X. Wu and S. P. Yang, Inorg. Chim. Acta, 2010, 363, 1755.

57 Q. Zhao, C. Y. Jiang, M. Shi, F. Y. Li, T. Yi, Y. Cao and C. H. Huang, Organometallics, 2006, 25, 3631.

58 Q. Zhao, S. J. Liu, M. Shi, F. Y. Li, H. Jing, T. Yi and C. H. Huang, Organometallics, 2007, 26, 5922.

59 H. B. Wei, Z. F. Zhao, C. Wei, G. Yu, Z. W. Liu, B. Zhang, J. Bian, Z. Q. Bian and C. H. Huang, Adv. Funct. Mater., 2016, 26, 2085. 